\title{
Does Corruption Attenuate the Effect of Red Tape on Exports? ${ }^{\dagger}$
}

\author{
Reshad N. Ahsan ${ }^{1, *}$ \\ ${ }^{1}$ Department of Economics \\ University of Melbourne.
}

Level 3, FBE Building, 111 Barry Street

*Email: rahsan@unimelb.edu.au.

${ }^{\dagger}$ I thank Robert Dixon, Roland Hodler, Devashish Mitra, Cong Pham, Walter Steingress, and conference and seminar participants at the Australasian Trade Workshop and Monash University for helpful comments and discussions. I also thank Mai Ly for her excellent research assistance. The standard disclaimer applies.

\section{Abstract}

In this paper I use firm-level data to examine whether corruption can attenuate the adverse effects of customsrelated red tape on exports. I find that the negative effect of red tape on exports is lower for firms in industries and countries where corruption at customs is more prevalent. This suggests that, conditional on there being customs-related red tape, a firm is better off if it can use bribes to lower the delay that it faces. However, I also find that corruption has a negative overall effect on a firm's decision to export. That is, corruption prevents some firms from entering the export market. Taken together, these results suggest that even if corruption does allow some firms to attenuate the red tape that that it faces, the overall effect of corruption need not be positive. To gauge the overall effect, we must compare the red-tape attenuating effects of corruption against its adverse effect on a firm's decision to export.

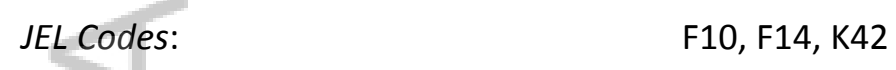

This Key has not been through the copyediting, typesetting, pagination and proofreading process, which

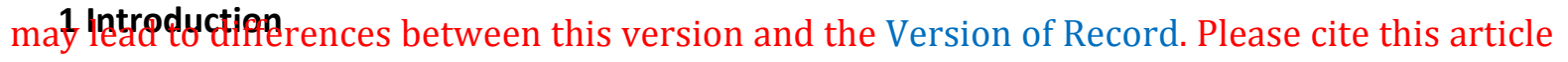
as doi: 10.1111/ecin.12445

This article is protected by copyright. All rights reserved. 
The ability to deliver goods and services on time is an increasingly important determinant of export success (World Bank, 2007). For instance, Djankov, Freund, and Pham (2010) find that an additional day spent prior to shipment reduces trade by more than one percent. Similarly, Volpe Martincus, Carballo, and Graziano (2015) find that an increase in customs delays lowers firm exports. While delays can be caused by various factors (e.g. poor infrastructure), one that is particularly problematic is customs-related red tape. This is because such red tape can have both a direct as well as an indirect effect on exports. The direct effect is simply the increase in delays due to additional red tape. The indirect effect is due to the fact that, by providing customs officials with greater discretionary power, such red tape can promote corruption. ${ }^{1}$ Thus, not only will red tape raise delays, it will also potentially increase the cost of exporting by requiring firms to bribe customs officials. It follows that the true transaction costs associated with such red tape may be greater in environments where corruption is more prevalent.

In this paper I empirically examine whether the effect of customs-related red tape on firm exports depends on the extent of corruption. In contrast to the discussion above, I show that corruption need not exacerbate the adverse effect of red tape and in fact may attenuate it. This is because the bribes paid by exporters may lead to their documents being processed in an expedited manner. The time saved due to this will lower the delay that an exporter faces. If the value of this reduction in delay is greater than the total bribe payment, then corruption will attenuate the adverse effects of red tape on exports.

To examine whether this "grease the wheels" effect exists in this context, I use firm-level data from the Business Environment and Enterprise Performance Surveys. These surveys were conducted jointly by the European Bank for Reconstruction and Development and the World Bank. The sample I use includes a rich set of information on firms from 25 Eastern European and Central Asian countries in 2005 and 2008. Apart from standard information on production, these data also report each firm's exports as well as information on its interaction with customs officials. I combine these data with information on customs-related red tape from the World Bank's Doing Business reports. These are an annual publications that document the constraints to conducting business around the world including the regulatory barriers faced by firms that trade across borders. One of the variables used to measure these regulatory barriers is the number of documents that exporters need to clear their goods through customs. This is my primary measure of customs-related red tape. 
With these data in hand, I examine whether the effect of red tape on exports depends on the prevalence of corruption in a firm's industry and country. I define the prevalence of corruption as the fraction of firms in an industry-country pair that make unofficial payments to customs officials. This means that my measure of corruption prevalence is specific to customs and is not a more general measure of corruption. The rationale behind my empirical strategy is that, if it is the case that corruption allows exporters to lower the delay they face at customs, then we should observe that the adverse effect of customs-related red tape will be relatively weaker in magnitude for exporters located in industry-country pairs where corruption is more prevalent. To account for other, unobservable industry characteristics, I include industry and year interaction fixed effects in all of my econometric specifications. Thus, when I examine whether the effect of customs-related red tape on firm exports depends on an industry's corruption prevalence, I am controlling for other unobserved, time-varying industry characteristics in a flexible manner.

My results suggest that the negative effect of greater red tape on firm exports is lower for firms in industries and countries where corruption at customs is more prevalent. In particular, my estimates suggest that, for a firm in an industry with the median level of corruption prevalence, adding a document needed to process goods through customs lowers the value of its exports by an additional 3.8 percentage points relative to a firm in an industry at the 75th percentile of corruption prevalence. These results imply that, conditional on there being customs-related red tape, an exporter is better off if it is in an environment where it can use bribes to lower the delay that it faces. Further, I find that corruption prevalence does not have a negative overall effect on the value of a firm's exports. Thus, these results provide support for the "grease the wheels" effect of corruption.

I then examine the effect of corruption and red tape on the extensive margin, i.e. on a firm's decision to export. Here I find that corruption once again attenuates the adverse effects of red tape. However, unlike the previous results, I now find that corruption has a negative overall effect on a firm's decision to export. In particular, I find that a 10 percentage point increase in the prevalence of corruption decreases the probability of exporting by 3.6 percentage points. I also find that this negative effect is stronger for relatively new firms and firms in timesensitive industries. Thus, my results suggest that the presence of corruption prevents some firms from entering the export market. This means that even if corruption can attenuate the adverse effects of red tape, its overall effect need not be positive. My results suggest that we must weigh the "grease the wheels" effect of corruption against it adverse effect on a firm's decision to export. ${ }^{2}$ 
This paper is related to a literature that documents the effect of corruption on trade. For instance, Sequeira and Djankov (2014) examine how corruption affects the choice of ports used by South African firms. They distinguish between "collusive" and "coercive" corruption. The former occurs when customs officials and firms collude to share the rents from an illegal transaction (e.g. under-reporting of export/import value) while the latter occurs when the customs officials extracts a bribe to provide a public service. Their results suggest that while collusive corruption increases the volume of trade through a corrupt port, coercive corruption diverts trade towards competing ports. A related paper is by Dutt and Traca (2010), who use a gravity framework to show that while greater corruption reduces trade at low levels of tariffs, it has the opposite effect at high levels of tariffs. In other words, in the latter case greater corruption can increase trade by allowing firms to avoid exorbitant tariffs. ${ }^{3}$ In contrast, Anderson and Marcouiller (2002) show that inadequate institutions, which they proxy using corruption and imperfect contract enforcement, lowers bilateral trade between countries. Their findings suggest that the adverse effect of inadequate institutions are stronger than the adverse effect of higher tariffs. More recently, Olney (2015) finds that corruption raises the probability of a firm exporting indirectly through an intermediary and lowers the probability of a firm exporting directly.

This paper is also related to a literature on the broader efficiency effects of corruption. This literature can be divided into two camps. The first camp argues that corruption distorts behavior away from the first best and thereby reduces welfare (Shleifer and Vishny, 1993; Rose-Ackerman, 1999). The second camp argues that corruption need not be detrimental. Instead, this literature argues that corruption can improve efficiency by allowing firms to circumvent excessive red tape and thereby attenuate its regulatory burden (Leff, 1964; Huntington, 1968; Lui, 1985; Dreher and Gassebner, 2013).

Lastly, this paper is related to a growing literature documenting the trade-increasing effects of greater trade facilitation, i.e. a reduction of delays and its associated transaction costs faced by firms at customs. For example, Wilson, Mann, and Otsuki (2004) use a gravity model to examine the effect of trade facilitation on trade volume. Their results confirm that such trade facilitation can have significant positive effects on trade. Similarly, Nordas, Pinali, and Geloso Grosso (2006) show that greater delays at the border have a significant negative effect on trade. As mentioned earlier, this result is confirmed by Djankov et al. (2010) and Volpe Martincus et al. (2015) who show that greater delays lower trade. A related literature examines the adverse effects of port inefficiency on shipping costs and trade flows. For instance, Clark, Dollar, and Micco (2004) find that increased port efficiency 
significantly lowers shipping costs while Blonigen and Wilson (2008) find that increased port efficiency significantly raises trade volumes.

I structure the remainder of this paper as follows. In section 2 I describe a simple conceptual framework that highlights both the export-reducing and export-increasing effects of corruption. In section 3 I describe the data I use to measure customs-related red tape, corruption prevalence, and firm exports. In section 4 I describe my econometric strategy while in section 5 I describe my results. Finally, in section 6 I provide a conclusion.

\section{Customs-Related Red Tape, Bribes, and Exports}

In this section I describe a simple conceptual framework with which I examine the effect of customs-related red tape on corruption and exports. The main purpose of this framework is to clarify the nature of corruption and exporter-customs official interaction that can allow corruption to attenuate the adverse effects of red tape. This framework is developed more formally in the online appendix. ${ }^{4}$ Here I provide a more informal description of the key result.

Consider a representative firm that operates in two stages. In stage 1, it takes as given the price of its product, $P^{*}$ (normalized to one), the delay it faces at customs, $\theta$, and the bribe it pays per unit of output to lower its delays, $b .{ }^{5}$ It then chooses its optimal level of output for export, $X$. In the second stage, the firm interacts with the customs official to clear its goods through customs. Having produced $X$ units of its product in the first stage, the firm's objective is to pick the bribe rate that allows it to minimize the delay, $\theta$, it faces at customs. In doing so, the firm must weigh the benefits of paying a bribe (lower $\theta$ ) against the cost of doing so (higher $b X$ ). Similarly, the customs official must weigh the benefit of corruption (higher $b X$ ) against the cost of doing so (higher expected punishment).

I assume that the amount of red tape mandated by the government, $D$, sets the upper bound on the delay faced by the firm, $\theta_{H}$. The customs official has the ability to impose lower delays on a particular shipment in exchange for bribes. One way to think about this is that a customs official requires $\theta_{H}$ units of time to thoroughly check the documents that the firm is required to complete. In exchange for a bribe, the official can agree to lower 
the thoroughness with which he reviews the firm's documents. In other words, firms pay bribes to encourage customs officials to "shirk" on their duties in order to save time. This implies that the delay faced by the firm, $\theta$, will be a function of both the red tape mandated by the government, $D$, and the bribe paid by firms, $b$, with $\theta_{D}>0$ and $\theta_{b}<0$.

In the online appendix, I show that, with this setup, we can state the effect of higher $D$ on exports as follows:

$$
\frac{\mathrm{d} X}{\mathrm{~d} D}=\frac{1}{c_{X X}}[-\underbrace{\left(\theta_{D}+b_{D}\right)}_{\text {Export-ReducingEffect }}-\underbrace{\theta_{b} b_{D}}_{\text {Export-IncreasingEffect }}]
$$

where $c_{X X}>0$ is the second derivative of the firm's total cost function. The first term inside the square brackets $\left(\theta_{D}+b_{D}\right)$ represents the export-reducing effect of greater red tape and corruption. It states that higher $D$ lowers exports in two ways. First, it raises the delay associated with clearing goods through customs $\left(\theta_{D}>0\right)$, which in turn lowers exports. Second, greater red tape means that a larger bribe must be paid to the customs official to lower delays $\left(b_{D}>0\right)$. This also lowers exports. On the other hand, the second term inside the square brackets $\left(\theta_{b} b_{D}\right)$ represents the export-increasing effect of corruption. This is due to the fact that the higher $b$ induced by red tape will also lower delays since $\theta_{b}<0$. This effect alone will raise a firm's exports. Thus, the net effect of corruption on the relationship between customs-related red tape and firm exports is uncertain. Importantly, it is possible for corruption to attenuate the overall effect of red tape on firm exports. ${ }^{6}$

Suppose that it is the case that firms are able to use bribes to attenuate the overall effect of red tape on its exports. This does not necessarily imply that corruption, on average, raises firm exports. The benefit of corruption to the firm is that it lowers the delay it faces to some value $\theta<\theta_{H}$. This is the well known "grease the wheels" hypothesis. If it is the case that $\left|\theta-\theta_{H}\right|=b$ then the overall effect of corruption on exports is zero. This is because, the firm is paying a bribe, $b$, that is equal to the value of the reduction in delay that the bribe has bought. It is also worth pointing out that, within this conceptual framework, the best-case scenario for the firm is 
one where there is complete trade facilitation, i.e. $D=0$. Here, the firm does not face a delay, does not have to pay bribes, and is able to export all of its output. Corruption is only useful in a second-best world where there are delays due to red tape and the firm is is able to use bribes to lower the delay it faces.

Going beyond this conceptual framework, corruption can lower the probability of exporting even if it attenuates the adverse effects of red tape on the value of exports. Suppose that greater corruption at customs leads to firms earning lower variable profits from exporting. For sufficiently high levels of corruption, this can prevent some firms from earning enough variable profit to cover the fixed costs of exporting. As a result, these firms will choose not to export at all. Further, it is likely that this adverse effect of corruption on the extensive margin will fall disproportionately on firms in time-sensitive industries that have weaker bargaining power in any negotiation with customs officials. Thus, in the context of interactions between exporters and customs officials, the fact that corruption may attenuate the adverse effects of red tape on the value of exports need not imply that it has a positive overall effect. To gauge this overall effect, we must be weigh the attenuating effect against the negative impact of corruption on the decision to export. ${ }^{7}$

\section{Data}

The firm-level data used in this paper are from the 2005 and 2008 Business Environment and Enterprise Performance Surveys (BEEPS) conducted jointly by the European Bank for Reconstruction and Development and the World Bank. ${ }^{8}$ My working sample consists of firms in manufacturing sectors in 25 European and Central Asian countries. Table 1 lists the countries included in the sample. The construction of this working sample is described in more detail in the online appendix.

The BEEPS data are unique because it collects information on each firm's business environment including the level of corruption it faces. For instance, the key bribery variable used in this paper is an answer to the following question, "thinking now of unofficial payments/gifts that establishments like this one (emphasis added) would make in a given year, please tell me how often would they make payments/gifts...to deal with customs/imports." ${ }^{9}$ Firms had the choice of selecting one of the six following options: (a) never, (b) seldom, (c) sometimes, (d) frequently, (e) usually, (f) always, and (g) don't know. Notice that the distinction between many of these options is not particularly clear, e.g. "seldom" vs. "sometimes". To ensure a more meaningful delineation between firms that do and do not bribe, I convert the answers provided in the raw data into an indicator variable that captures 
whether or not a firm pays bribes to customs officials. This indicator variable takes the value of one if a firm answers with any of the options (b) to (f) to the question above. For firms that respond with option (a) to this question, the indicator variable takes the value of zero. ${ }^{10}$

The data suggest that corruption among customs officials was fairly widespread in the sample. Over the two sample years, 33.7 percent of exporters in the sample report paying bribes to a customs official. In fact, 10.4 percent of exporters report paying such bribes either "frequently", "usually", or "always". As Figure 1 illustrates, the prevalence of corruption varies markedly across countries in the sample. For example, 75 percent of Albanian exporters in the sample report paying such bribes whereas only 10.3 percent of Slovenian exporters report paying such bribes. Further, as documented in Table 2, the prevalence of corruption among customs officials decreased during the sample period. Nonetheless, despite this improvement, it is clear that customs and particularly corruption among customs officials is not a trivial barrier to exporters in the sample.

In addition to collecting information on the business environment faced by firms, the survey also asked firms to report a standard list of variables such as sales, employment, exports, and ownership information. In particular, firms were asked to list the percentage of their sales that were (a) sold domestically, (b) exported directly, and (c) exported indirectly through a distributor. I define a firm as an exporter if it reports exporting directly. These firms represent 35 percent of the sample. The share of exporters in the BEEPS sample falls within the range of numbers reported by Mayer and Ottaviano (2007) for a select list of six European countries. ${ }^{11}$ In addition, exports represent approximately 43 percent of sales for the average exporter in the sample. As Table 3 indicates, the exporters in the sample tend to be larger, older, and have higher levels of foreign investment. Table 3 also reports the means and standard deviations of all variables used in the paper. The typical firm employs 37 permanent workers and has been in business for about 17.9 years. While the average firm was mostly privately owned, approximately 13 percent of firms report having some foreign ownership. Table C.1 in the online appendix lists the key variables used in the paper along with their source.

To capture the extent of customs-related red tape I use the number of documents needed to export in each country. These data are from various Doing Business reports, which are annual publications from the World Bank that document the constraints to conducting business around the world. One of the constraints documented in these reports is the difficulty of trading across borders. This is essentially an evaluation of the constraints to 
importing and exporting in various countries. To quantify these constraints, the Doing Business reports recorded every official document needed to export a standardized cargo of goods in each country.

The information on the documents needed to export was gathered using surveys administered on local freight forwarders, shipping lines, customs brokers, and port officials. To ensure that the data are comparable across countries, each survey respondent was asked to consider traded products that travel in a dry-cargo, 20-foot, full container. They were also asked to consider products that are not hazardous, that do not require refrigeration and meets international phytosanitary and environmental safety standards (Djankov et al., 2010). Further, respondents were asked to consider all documents required per export shipment. Thus, any documents that are valid for a year or longer or do not have to be acquired for every shipment are not included in these data. For landlocked countries, the data on the documents needed to export also include documents required by the transit countries. The number of documents needed varies markedly across countries in the sample. For instance, an exporter in the Kyrgyz Republic requires 15 documents to export whereas an exporter in Estonia only requires 3 documents. As a robustness check, I also use the total number of days needed to process goods through customs to proxy for the extent of customs-related red tape in a country. These data are also collected by the World Bank in its Doing Business reports.

\section{Econometric Strategy}

\subsection{Specification}

To examine the effect of customs-related red tape on the value of firm exports I estimate the following econometric specification:

$$
\ln \left(X_{i j c t}\right)=\beta_{0}+\beta_{1} D_{c t}+\beta_{2} B_{j c t}+\beta_{3} B_{j c t} \times D_{c t}+\beta_{4} F_{i j c t}+\beta_{5} Z_{c t}+\sum_{r=1}^{2} \delta_{r}+\delta_{j} \times \delta_{t}+v_{i j c t}
$$

where $X_{i j c t}$ is the total value of exports for firm $i$ in two-digit industry $j$, country $c$, and year $t .{ }^{12} D_{c t}$ is the total number of documents needed to process export goods through customs in a given country and year and

$B_{j c t}$ is the prevalence of corruption in an industry and country. ${ }_{j c t}$ is defined as the fraction of firms in a given industry, country, and year that report making unofficial payments when dealing with customs officials. Thus, it 
captures the likelihood that a firm will be solicited for bribes by customs officials.

As the discussion in section 2 highlighted, the effect of corruption on exports can be divided into two components: (a) an export-reducing effect and (b) an export-increasing effect. The former captures the fact that higher corruption will lower exports directly by raising the cost of exporting. On the other hand, greater corruption will allow exporters to lower the delay that it faces. This will increase exports. To separate these two components I add the interaction between $B_{j c t}$ and $D_{c t}$ in (2). Here $\beta_{3}$ captures the attenuating/exacerbating effect of corruption. A positive $\beta_{3}$ means that, holding other industry characteristics constant, in industries where corruption is more prevalent, the negative effect of a given increase in $D_{c t}$ on exports is relatively smaller. This is consistent with firms using bribes to attenuate the effects of greater customs-related red tape on their exports.

\section{$F_{i j c t}$ is a set of firm-level control variables that includes the natural logarithm of total permanent employees,} age, age squared, and an indicator for whether a firm has foreign ownership. $Z_{c t}$ is a set of country-level control variables that includes the natural logarithm of GDP per capita and the growth rate of GDP. $\delta_{r}$ is a fixed effect for region $r .{ }^{13}$ Given that countries in the same region are likely to have similar geography and factor endowments, these region fixed effects will control for such factors. ${ }^{14}$ Finally, $\delta_{j} \times \delta_{t}$ are two-digit industry and year interaction fixed effects while $\varepsilon_{i j c t}$ is a classical error term.

\subsection{Threats to Identification}

The first threat to identification that I address is the possibility that both firm-level exports and corruption are correlated with unobservable firm characteristics. The specification in (2) already controls for a set of observable firm-level characteristics, but given that the data are a pooled cross-section, it does not include firm fixed-effects to control for unobservable, time-invariant firm characteristics. This would be an especially serious problem if (2) included the actual bribes paid by firms, $b_{i j c t}$, and its interaction with $D_{c t}$. To circumvent this problem, I use an industry's corruption prevalence, $B_{j c t}$, as a proxy for the expected bribes paid by firms. The identifying assumption here is that an industry's corruption prevalence is uncorrelated with unobservable firm 
characteristics. $^{15}$

A second threat to identification is the presence of unobservable industry characteristics that are correlated with both the prevalence of corruption in an industry $\left({ }^{B_{j c t}}\right)$ and the level of exports by a firm $\left(X_{i j c t}\right)$. For instance, it could be the case that both $B_{j c t}$ and $X_{i j c t}$ are correlated with unobservable industry-specific demand shocks as well as unobservable changes in industry-specific productivity or technological change. To address such concerns, I add industry and year interaction fixed effects to all specifications estimated in this paper. The inclusion of these interaction fixed effects will flexibly capture any time-varying, unobservable industry characteristic that is correlated with both $B_{j c t}$ and $X_{i j c t}$.

A third threat to identification is the potential that customs-related red tape is itself a function of the prevalence of corruption. For instance, suppose that a fraction of the bribes extracted by customs officials are passed along to more senior bureaucrats who determine the amount of red tape that firms face. These senior bureaucrats will then have an incentive to adjust red tape to maximize their bribe earnings. To the extent that this is the case, my estimates in (2) will be biased. To account for this, I instrument $B_{j c t}$ with the corruption prevalence in industry $j$ in all countries with which $c$ shares a border. Let the set of contiguous countries be indexed by $c^{\prime}=1,2, \ldots, n-1$. It follows that the instrument is

$$
B_{j c^{\prime} t}=\sum_{c^{\prime}=1}^{n-1} \frac{b_{j c^{\prime} t}}{N_{j c^{\prime} t}}
$$

where $b_{j c^{\prime} t}$ is the number of firms in industry $j$ and country $c^{\prime}$ that report paying bribes to customs officials and $N_{j c^{\prime} t}$ is the total number of firms in industry $j$ and country $c^{\prime}$. The validity of this instrument rests on two assumptions. The first is that the prevalence of corruption in an industry in country $c$ is correlated with the prevalence of corruption in the same industry in a contiguous country $c^{\prime}$. This will be the case if industries have certain characteristics that make it a target for corrupt customs officials and that these characteristics are common across contiguous countries. One such characteristic is the extent of an industry's comparative 
advantage. For instance, suppose that $j$ is a comparative-advantage industry in country $c$. All else equal, the average firm in this industry will have higher exports, which will make them a target for corrupt customs officials. Given that it's neighboring countries are likely to have similar relative factor endowments and levels of development (hence similar levels of technology), it is likely that $j$ will also be a comparative advantage sector in $c^{\prime}$. Thus, customs officials in $c^{\prime}$ will similarly target firms in this industry. To the extent that this is the case, there will be a correlation between $B_{j c t}$ and $B_{j c^{\prime} t}$ for any two contiguous countries $c$ and $c^{\prime}{ }^{16}$

The second assumption needed for $\stackrel{\square}{B}_{j c^{\prime} t}$ to be a valid instrument for $B_{j c t}$ is that the former is unrelated to the level of red tape in $c$. This implies that when a bureaucrat in country $c$ chooses the optimal level of red tape there, $D_{c t}$, his choice is not affected by the possibility of earning bribes from firms in contiguous countries. The implementation of this instrumental variable approach is described in more detail in section 5.2, where I also discuss and address confounding factors that may invalidate this exclusion restriction assumption.

A fourth threat to identification is the presence of omitted country characteristics that are correlated with $X_{i j c t}$, $B_{j c t}$, and the number of documents needed to export, $D_{c t}$. As mentioned above, there is limited inter-temporal variation in a country's documents needed to export in my data. This means that the identification of $D_{c t}$ is mainly due to cross-sectional variation, which makes it difficult to include country fixed effects. Instead, I've included a set of country-level controls as well as region fixed effects. The use of this approach means that my coefficients of interest may be biased by the presence of omitted country characteristics. To account for this, I add other country characteristics that are potentially related to both customs red tape and firm exports. As I show in 5.3 , adding these country characteristics do not significantly change the key results of the paper. In fact, in the majority of these cases, the additional characteristics are statistically insignificant.

\subsection{Estimation Method}

Given that a large fraction of firms in the sample are non-exporters, equation (2) represents a standard corner solution model (Wooldridge, 2010). To account for the large number of zeroes I estimate this equation using 
Tobit. ${ }^{17}$ Given that Tobit is a nonlinear model, I report the marginal effects of each variable of interest on $\mathrm{E}(X)$. In particular, the marginal effect of $D_{c t}$ that I calculate is:

$$
\begin{aligned}
& \frac{\partial \mathrm{E}[X]}{\partial D_{c t}}=\left(\beta_{1}+\beta_{3} B_{j c t}\right) \Phi(\mu) \\
& = \\
& \text { where } \mu=\left(\beta_{0}+\beta_{1} D_{c t}+\beta_{2} B_{j c t}+\beta_{3} B_{j c t} \times D_{c t}+\beta_{4} F_{i j c t}+\beta_{5} Z_{c t}+\sum_{r=1}^{2} \delta_{r}+\delta_{j} \times \delta_{t}\right) / \sigma \text { and } \Phi(\mu) \text { is the }
\end{aligned}
$$

standard normal cumulative distribution function. Next, the marginal effect of $B_{j c t}$ is:

$$
\frac{\partial \mathrm{E}[X]}{\partial B_{j c t}}=\left(\beta_{2}+\beta_{3} D_{c t}\right) \Phi(\mu)
$$

Finally, the interaction term in equation (2) does not have an interpretation that is analogous to linear models. As Ai and Norton (2003) point out, the magnitude of the interaction effect in non-linear models does not necessarily equal the magnitude of the marginal effect of the interaction term. To correctly calculate the interaction effect we need to account for all necessary cross derivatives. For instance, using equation (4), we can derive the following formula for the total interaction effect:

$$
\frac{\partial^{2} \mathrm{E}[X]}{\partial D_{c t} \partial B_{j c t}}=\beta_{3} \Phi(\mu)+\left(\beta_{1}+\beta_{3} B_{j c t}\right)\left(\frac{\beta_{2}+\beta_{3} D_{c t}}{\sigma}\right) \phi(\mu)
$$

where $\phi(\mu)$ is the standard normal probability density function. The first term on the right-hand-side, $\beta_{3} \Phi(\mu)$, is the marginal effect of the interaction term. From the above expression, we can see that the marginal effect of the interaction term is not equivalent to the overall interaction effect. In fact, even if $\beta_{3}$ is equal to zero, the interaction effect could be non-zero.

To calculate the marginal effects above I replace the $\beta$ 's and $\sigma$ with their respective Tobit estimates. I also substitute the average value of $D_{c t}$ and $B_{j c t}$ where appropriate. I then use STATA's nlcom command to calculate 
the marginal effects in equations (4) to (6). This yields both an estimate for each marginal effect along with their respective standard errors, which is calculated using the Delta method.

\section{Results}

\subsection{Baseline Results}

In column (1) of Table $4 \mathrm{I}$ begin by presenting the overall effect of the number of documents needed to export alone. I estimate this regression using OLS. The coefficient of this variable is negative and statistically significant. It suggests that adding a document needed to process export goods through customs lowers firm exports. In column (2) I report the results from estimating equation (2) using OLS. Here I add a time-varying, country and industry specific measure of corruption prevalence and its interaction with the number of documents needed to export. The coefficient of this interaction term is positive and statistically significant. This suggests that the impact of greater red tape is attenuated for firms in industries where corruption is more prevalent. This is consistent with firms using bribes to lower the regulatory burden that they face when clearing their goods through customs. To gauge the magnitude of the attenuating effect of corruption, consider two firms. Let the first firm be in an industry that has the median level of corruption prevalence and let the second firm be in an industry with a corruption prevalence at the 75th percentile. The results in column (2) suggest that the adverse impact of one additional document needed to export for the latter firm is 3.9 percentage points lower when compared to the former firm. ${ }^{18}$

In column (3) I once again report the overall effect of the number of documents needed to export alone. However, I now estimate this regression using Tobit. The reported result is the marginal effect of documents needed to export, which I calculate as follows

$$
\frac{\partial \mathrm{E}[X]}{\partial D_{c t}}=\beta_{1} \Phi(\mu)
$$

where $\beta_{1}$ is the coefficient of the documents needed to export variable, $\Phi(\mu)$ is the standard normal cumulative distribution function, and $\mu$ is as defined below equation (4). As is evident in column (3), this marginal effect is negative and statistically significant, which confirms that greater customs-related red tape reduces firm 
exports.

In column (4) of Table 4 I report the results from estimating equation (2) using Tobit. For each variable, I report the marginal effects evaluated at the mean of all other variables. This is the case for all marginal effects reported from hereon. The marginal effect of the documents needed to export variable is calculated using equation (4). The estimate again suggests that adding a document needed to process goods through customs lowers firm exports. Next, the magnitude of the interaction effect is calculated using equation (6). This estimate suggests that the adverse effect of an increase in the number of documents needed to export is smaller for firms in industries where corruption is more prevalent. As mentioned above, this is consistent with firms using bribes to lower the regulatory burden that they face when clearing their goods through customs.

To gauge the magnitude of the attenuating effect of corruption, again consider two firms. As before, let the first firm be in an industry that has the median level of corruption prevalence while the second firm is in an industry with a corruption prevalence at the 75th percentile. The results in column (4) suggest that the adverse impact of one additional document needed to export for the latter firm is 3.8 percentage points lower when compared to the former firm. To further illustrate the heterogeneous effect of customs-related red tape, I plot the marginal effect (along with the 95 percent confidence interval) of customs-related red tape at various deciles of corruption prevalence in Figure 3. More precisely, I calculate and plot the marginal effect in equation (4) at various deciles of corruption prevalence. ${ }^{19}$ This figure confirms that customs-related red tape has stronger adverse effects on firm exports in industries where corruption is less prevalent. ${ }^{20}$ This suggests that bribes are an effective way for firms to attenuate the adverse effects of customs-related red tape on firm exports.

To validate my baseline results, I next examine whether the adverse effects of red tape and the attenuating effect of corruption are more important for firms producing time-sensitive products. To examine whether this is the case, I categorize industries as having either time-sensitive or time-insensitive products with the method used by Volpe Martincus et al. (2015). ${ }^{21}$ In column (5) of Table 4 I restrict the sample to industries with time-sensitive products (time-sensitive industries from hereon) and estimate equation (2). When compared to the results in column 4, these results confirm that delays have stronger effects on firm exports for firms in time-sensitive industries and that the attenuating effect of corruption is also stronger in these industries. Similarly, in column (6) I restrict the sample to time-insensitive industries and estimate equation (2). These results suggest that delays 
have weaker effects (relative to the baseline sample) on firm exports for firms in time-insensitive industries and that corruption does not have a statistically significant attenuating effect for these firms. ${ }^{22}$

\subsection{Additional Industry Characteristics}

The econometric strategy I use assumes that any heterogeneous effect of red tape on firm exports is due to variation in the prevalence of corruption in an industry-country pair. However, it could be the case that corruption prevalence is correlated with other industry characteristics and that these alternate characteristics are the source of the heterogeneous effects of red tape. To address this, I sequentially add various industry characteristics along with its interaction with red tape to my baseline specification. I report the results from these regressions in Table 5.

In column (1) I add the average sales (in natural logarithm) in an industry, country and year cell along with its interaction with customs-related red tape to my baseline specification. This average sales variable is calculated using the firm-level, BEEPS data used in this paper and will control for the fact that in industries where the average firm is large, firms may be able to devote more resources to negotiating with customs officials and thereby minimize the adverse effects of red tape on their exports. To the extent that the average firm size in an industry is correlated with the prevalence of corruption, the coefficient of the interaction term of interest might be picking up the heterogeneous effects based on average firm size rather than corruption prevalence. However, as the results in column (1) demonstrate, the inclusion of average firm size and its interaction with customsrelated red tape does not alter the key results of the paper. I still find that adding a document needed to process goods through customs lowers the value of goods exported for the average firm and that this effect is attenuated for firms in industries where corruption is more prevalent.

Next, I add proxies for the average productivity of firms in an industry as well as its interaction with customsrelated red tape to my baseline specification. This addresses the following concern. Suppose that in highproductivity industries firms are more efficient in preparing the necessary documents needed for export. This will allow them to minimize the delay-increasing effects of customs-related red tape. This also means that the heterogeneous effects of red tape that I have documented thus far could be driven by differences in average firm productivity in an industry rather that corruption prevalence. 
To address this I use two proxies for average firm productivity in an industry. In column (2) of Table 5 I add the skill intensity of an industry, country, and year cell along with its interaction with red tape to my baseline specification. Skill intensity is defined as the ratio of non-production to production workers and is first calculated at the firm level using the BEEPS data. I then aggregated this to the industry, country, and year level by calculating a simple average. As before, the inclusion of these two variables in the baseline specification does not alter the key results of the paper. In column (3) I include the average labor productivity in an industry, country and year cell along with its interaction with red tape. Labor productivity is defined as the natural logarithm of a firm's sales to permanent employment ratio. I aggregated this to the industry, country, and year level using a simple average. Once again I find that the marginal effects of interest remain robust.

In column (4) I allow customs-related red tape to have heterogeneous effects on firm exports through variation in the fraction of an industry's products that are shipped by air. This will address the fact that the impact of red tape on delays and firm exports may depend on the extent to which alternate, faster transport is available. For instance, suppose a firm's product is sufficiently lightweight such that air shipment is feasible. In this case, firms may attenuate the effect of greater customs-related red tape on delays and exports by increasingly using air shipment. This could also explain the heterogenous effects of red tape that I have documented thus far. I use data from Hummels and Schaur (2013) to calculate, for each industry, the fraction of imports (by value) arriving in to the U.S. by air over their sample period of 1991 to 2005. I then include the interaction between this variable and customs-related red tape to my baseline specification. ${ }^{23}$ As the results in column (4) demonstrate, the key results remain robust to this inclusion.

Lastly, in column (5) I allow customs-related red tape to have heterogeneous effects on firm exports through variation in the fraction of an industry's products that are differentiated. Products that are more differentiated are ones for which it is more difficult to assess the actual value of a shipment (Sequeira and Djankov, 2014). This may mean that, for a given level of red tape, firms with differentiated products will face greater delays. To examine whether this matters, I calculate each industry's fraction of differentiated products using the Rauch (1999) classification. I then add the interaction between this fraction and customs-related red tape to my baseline specification. ${ }^{24}$ The results are reported in column (5) of Table 5. As these results show, the inclusion of this additional interaction term does not appreciably change my baseline results. 
As mentioned in section 4.2, my identification strategy thus far has relied on the assumption that the level of red tape imposed on exporters is not a function of the prevalence of corruption. In many scenarios, such an assumption is invalid. For instance, it could be the case that senior bureaucrats receive a fraction of the bribes extracted by customs officials. If so, they will have an incentive to adjust the level of red tape to maximize their bribe earnings. To account for this, I instrument the endogenous variable ${ }^{B_{j c t}}$ using the average prevalence of corruption in industry $j$ and year $t$ for all countries with which $c$ shares a border. This instrument is discussed in greater detail in section 4.2 .

Given that my baseline specification is estimated using Tobit, I use the Smith and Blundell (1986) control-function approach to implement this instrumental variable strategy. This is done in two stages. In stage 1, I regress each endogenous variable ( $B_{j c t}$ and $B_{j c t} \times D_{c t}$ respectively) on the instruments $\left(\stackrel{\square}{B}_{j c t}\right.$ and $\left.\stackrel{\square}{B}_{j c t} \times D_{c t}\right)$ along with the other exogenous variables in equation (2). I then collect the residuals from both OLS regressions. Let these residuals be $\hat{v}_{1, i j c t}$ and $\hat{v}_{2, i j c t}$ respectively. Then, in the second stage, I add the estimated residuals to equation (2). This yields the following specification

$$
\begin{aligned}
& \ln \left(X_{i j c t}\right)=\beta_{0}^{C F}+\beta_{1}^{C F} D_{c t}+\beta_{2}^{C F} B_{j c t}+\beta_{3}^{C F} B_{j c t} \times D_{c t}+\beta_{4}^{C F} F_{i j c t}+\beta_{5}^{C F} Z_{c t}+\sum_{r=1}^{2} \delta_{r}+\delta_{j} \times \delta_{t} \\
& +\rho_{1} \hat{v}_{1, i j c t}+\rho_{2} \hat{v}_{2, i j c t}+v_{i j c t}^{C F}
\end{aligned}
$$

Here $\hat{v}_{1, i j c t}$ and $\hat{v}_{2, i j c t}$ "control" for the endogeneity of $B_{j c t}$ and $B_{j c t} \times D_{c t}$. I then estimate (7) using Tobit. Table 6 reports the results from using this instrumental variable strategy. In column (1) I estimate (2) using using

conventional 2SLS where I use $\vec{B}_{j c t}$ and $\stackrel{\square}{B}_{j c t} \times D_{c t}$ to instrument the endogenous variables $B_{j c t}$ and $B_{j c t} \times D_{c t}$. As the results demonstrate, the sign of the marginal effects of interest remain unchanged after the instrumental variable strategy is used. In fact, the magnitude of the interaction term is greater with the instrumental variable approach. Importantly, the instruments themselves are sufficiently strong. The Shea's partial $R^{2}$ for the instruments ranges between 0.28 and 0.34 . In column (2) I report the results form estimating (7) using Tobit. The 
reported marginal effects have the same sign as the baseline results. ${ }^{25}$ Further, as was the case with the conventional 2SLS results, the magnitude of the marginal effects are greater here. Both of these results point to the baseline results being attenuated due to measurement error. ${ }^{26}$

As mentioned in section 4.2, my instrumental variable strategy relies on the assumption that the corruption prevalence in country $c^{\prime}$ is unrelated to the level of red tape in $c$. The most obvious case in which this assumption will be violated is when a country is landlocked. As an example, suppose country $c^{\prime}$ is landlocked and suppose that firms in $c^{\prime}$ use the ports in $c$ to export their goods. In this case, the level of red tape if $c, D_{c t}$, may

be correlated with both $B_{j c t}$ and $B_{j c^{\prime} t}$ and thereby invalidate my instrument. To account for this I also implement my instrumental variable strategy on a sample that excludes landlocked countries. I use the data created by Mayer and Zignago (2011) to classify a country in my sample as either being landlocked or not. Here I not only exclude landlocked countries from the working sample, I also exclude them from the instrument calculation. That is, I now omit landlocked countries before calculating (3). The reported marginal effects in column (3) of Table 6 have the same sign as the baseline results as well as the results in column (2). Further, the marginal effects of $D_{c t}$ and $B_{j c t} \times D_{c t}$ are precisely estimated. Thus, we can conclude that omitting landlocked countries does not yield conclusions that differ from the results in column (2).

\subsection{Additional Country Characteristics}

Thus far, my baseline econometric specification has not included country fixed effects. This is because, as illustrated in Figure 2, the data on the number of documents needed to export ( $D_{c t}$ ) does not vary significantly over time. This means that the effects of $D_{c t}$ that I am identifying are mainly due to cross-sectional variation, which makes it difficult to include country fixed effects. ${ }^{27}$ Instead, I've included a set of country-level controls as well as region fixed effects. One omitted country characteristic that might raise concerns is the export intensity of a country. It could be the case that countries that are highly export-oriented will already have streamlined its customs-related red tape and also put in place measures to limit corruption by customs officials. Further, we would expect the export behavior of firms in a country to be correlated with the export intensity of the country itself. To the extent that this is the case, omitting a country's export intensity might confound my regression 
estimates. To address this I use data from the World Bank's Worldwide Governance Indicators to measure each country's ratio of merchandise exports to GDP to capture its export intensity. I then include this variable in my baseline specification. Recall that the baseline specification already includes the natural logarithm of a country's GDP per capita, its GDP growth rate, and region fixed effects. As the results in column (1) of Table 7 indicate, my primary results remain highly robust to the inclusion of this additional variable. Further, as expected, the marginal effect of merchandise exports is positive and statistically significant.

In column (2) I include instead an indicator for whether a country is landlocked to my baseline specification. Firms in a landlocked country face an additional layer of customs-related bureaucracy as they have to clear customs in their own country as well as in the country whose port it uses to transport its goods. Further, given the transportation costs associated with this added travel, a firm's exports will be directly correlated with whether or not it is in a landlocked country. However, as the results in column (2) suggest, the inclusion of a landlocked indicator does not alter the key results of the paper. Further, the marginal effect of the landlocked indicator is itself statistically insignificant.

In the paper thus far, I have assumed that it is red tape faced when clearing goods through customs that adversely affect a firm's exports. However, it could be the case that the red tape that is most important is faced by firms earlier in the export process. For example, firms may be hindered by regulations that distort their day-to-day activities or by regulations that make it more difficult to invest or start a business. To the extent that such regulations are correlated with customs-related red tape, my results might be picking up the effects of broader regulations. To address this, I include a regulatory quality index to my baseline specification in column (3). This index is from the Worldwide Governance Indicators that are maintained by the World Bank. It "captures perceptions of the ability of the government to formulate and implement sound policies and regulations that permit and promote private sector development." According to the marginal effects reported in column (3), the primary results of the paper are robust to the inclusion of this additional variable. Further, the marginal effect of the regulatory quality variable itself is positive and statistically significant. This suggests a better overall regulatory environment raises firm exports.

Next, in column (4) I add a measure of the ease of starting a new business in a country to my baseline specification. These data are part of the Doing Business Report collected by the World Bank and capture the 
number of procedures an entrepreneur needs to undertake to incorporate and register a new firm. Once again, the primary results of the paper are robust to the inclusion of this additional variable. In addition, the marginal effect of this additional variable is itself statistically insignificant. Lastly, in column (5) I include both a country's ratio of merchandise exports to GDP and its regulatory quality to the baseline specification. Recall that both of these variables had a statistically significant effect on firm exports. The marginal effects in column (5) confirm that the key results of the paper remain robust when both of these additional variables are included simultaneously.

\subsection{Robustness Checks}

In Table 8 I subject the primary results of this paper to a series of robustness checks. In column (1) I use a timeinvariant measure of corruption prevalence. This version of corruption prevalence still captures the fraction of firms in a given industry and country that report making unofficial payments when dealing with customs officials. However, it only varies by industry and country and not by year. The results in column (1) suggests that using this time-invariant version does not change the primary results in a significant manner. In column (2) I replace the default measure of red tape (number of documents needed to process goods through customs) with the natural logarithm of the number of days needed to process goods through customs. Despite the strong correlation between them (correlation coefficient of 0.76 ), I do not treat these two proxies for red tape symmetrically. This is because the time needed to clear customs is a function of the extent of red tape mandated by the government as well as the endogenous choices made by customs officials and firms when they agree on the amount of bribes to be paid. On the other hand, the number of documents needed to clear customs is set by the government and is independent of the agreement process between the customs official and the firm. For this reason, I treat the latter as my primary proxy for red tape while I use the former as a test of the robustness of my results. Nonetheless, it is reassuring that the estimates in column (2) of Table 8 strongly support my primary results.

Next, in column (3) I use the customs-specific logistics performance index (LPI) for each country as an alternate measure of customs-related red tape. This index was constructed by the World Bank using survey responses from multinational freight forwarders and express carriers and scores the "efficiency of the clearance process by customs and other border agencies" in each country (World Bank, 2007). The score is provided on a numerical scale from 1 (worst) to 5 (best). To ensure easier comparison with my primary measure of customs red tape, I use a modified score that is defined as 5- LPI, where LPI is the original index score for each country. The modified 
score is therefore increasing in logistics inefficiency. ${ }^{28}$ These data were first collected in 2007 , which is the year I use. Thus, in my analysis, this index varies by country but not year. As the results in column (3) demonstrate, the key results of the paper are robust to using this alternate measure of customs-related red tape.

In column (4) I use each firm's export intensity as the dependent variable. This is defined as the ratio of each firm's exports to sales. As the estimates in this column confirm, the primary results of the paper are robust to the use of export intensity as the dependent variable. Next, as mentioned in section 3, when measuring a firm's exports I have used their direct exports only and ignored any indirect exports that they may have. These indirect exports represents a firm's sales overseas through the use of a distributor. To examine whether the key results of the paper are robust to the inclusion of indirect exports, I use the natural logarithm of all exports as the dependent variable in column (5) of Table 8. In particular, the dependent variable is the sum of direct and indirect exports (in natural logarithm). As these estimates indicate, using all exports in place of only direct exports does not change the key conclusions of the paper.

\subsection{Extensive Margin}

My analysis thus far has focused on the effect of export-related red tape and corruption on the value of exports. I have found that corruption attenuates the adverse effects of red tape on the total value of exports and does not have a statistically significant overall effect on exports. In this section, I examine whether this result holds on the extensive margin of exports. That is, I now ask whether corruption also attenuates the adverse effects of red tape on the decision to export and whether it has a negative overall effect on this decision. To do so, I change the dependent variable in (2) to an indicator that takes the value of one if a firm exports in any given year and is zero otherwise. I then estimate this specification using probit.

The results from this extensive margin regression are reported in Table 9. In column (1) I report the results from estimating this new specification on the entire sample. The results suggest that greater red tape lowers the probability of exporting. It also suggests that greater corruption prevalence attenuates the adverse effects of export-related red tape. Thus, these two marginal effects yield conclusions that are similar to the previous results. However, I now find that greater corruption prevalence has a negative overall effect on the probability of exporting. In particular, the results suggest that a 10 percentage point increase in the prevalence of corruption decreases the probability of exporting by 3.6 percentage points. This result suggest that while corruption allows 
firms to attenuate the adverse effect of red tape on the probability of exporting, it's overall effect lowers this probability. Recall from Table 4 that corruption prevalence did not have a negative overall effect on the value of exports.

As before, I examine whether the effect of corruption and red tape on the decision to export varies according to the time-sensitivity of an industry's products. I classify each industry in my sample as either being time sensitive or time insensitive using the method described in section 5.1. In column (2) of Table 9 I restrict the sample to timesensitive industries. All three marginal effects of interest have the same sign as in column (1) and are precisely estimated. Importantly, the magnitude of both the interaction effect as well as the overall effect of corruption prevalence is greater than in column (1). In column (3) I restrict the sample to time-insensitive industries. Here I find that corruption has neither a statistically significant attenuating effect nor a statistically significant overall effect on the decision to export. The results in columns (2) and (3) suggest that the overall effect of corruption on the decision to export is especially adverse for firms in time-sensitive industries.

Next, I examine whether the adverse overall effect of corruption prevalence on the extensive margin of export depends on an exporter's characteristics. In columns (4) and (5) of Table 9 I re-estimate the extensive margin regression for large and small firms respectively. To place firms into these two categories, I first calculate each firm's total number of permanent employees. I then classify a firm as large if its total number of permanent employees is greater than or equal to the sample median. All other firms are categorized as small. The results in columns (4) and (5) suggest that, for both types of firms, customs red tape lowers the probability of exporting and corruption attenuates this effect. In addition, corruption has a negative overall effect on the probability of exporting for both type of firms.

Lastly, in columns (6) and (7) I examine whether a firm's age influences the effect of red tape and corruption on the probability of exporting. In particular, I categorize a firm as old if its average age is greater than or equal to the sample median. All other firms are classified as new. The results in columns (6) and (7) suggest that the adverse effect of corruption on the decision to export is much more severe for relatively new firms. Thus, the results in Table 9 suggest that while corruption may allow firms to attenuate the adverse effects of red tape on the value of exports as well as the decision to export, it has a negative overall effect on the latter. Further, this negative effect is greater for firms that are relatively new as well as for firms that are in time-sensitive industries. This means that 
the beneficial effect of corruption identified previously must be weighed against the fact that corruption prevents some firms from accessing the export market.

\section{Conclusion}

This paper contributes to a growing literature documenting the adverse effects of customs-related red tape on exports. In theory, the adverse effects of such red tape could be exacerbated in countries where corruption is prevalent. This is because government regulations provide an opportunity for bureaucrats to engage in rentseeking behavior (Krueger, 1974). This means that the presence of customs-related red tape may allow customs officials to extract bribes from exporters. On the other hand, the higher bribes induced by customs-related red tape may allow exporters to lower the delays that they face. This is the well-known "grease the wheels" hypothesis. Thus, in this context, corruption may have an important benefit if it allows firms to lower their regulatory burden.

I empirically explored whether corruption can allow exporters to attenuate the adverse effects of red-tape using firm-level data from the Business Environment and Enterprise Performance Surveys. These surveys provide information on firm exports as well as the prevalence of corruption at customs. I also used data from the World Bank's Doing Business reports to measure the number of documents needed to process goods through customs for each country in my sample. I used these data to examine whether the adverse effects of red tape on firm exports was lower for a firm in an industry with a comparatively greater prevalence of corruption. My results indicated that this was indeed the case. In particular, I found that the adverse impact of one additional document on the value of a firm's exports was 3.8 percentage points lower for a firm in an industry at the 75th percentile of corruption prevalence when compared to a firm in an industry with the median corruption prevalence. This result is consistent with firms using bribes to lower the regulatory burden that they face when clearing their goods through customs.

I then explored the impact of corruption on the extensive margin, i.e. on a firm's decision to export. Here I again found that corruption attenuates the adverse effects of red tape. However, unlike the earlier results, I also found that corruption has a negative overall effect on the decision to export. In particular, I found that a 10 percentage point increase in the prevalence of corruption decreases the probability of exporting by 3.6 percentage points. This negative effect was stronger for relatively new firms and firms that are in time-sensitive industries. 
Thus, my results suggest that in a second-best world with incomplete trade facilitation, i.e. a world in which customs-related red tape exists, corruption may allow firms to attenuate the adverse effects of red tape on their exports. However, it does not follow that the net effect of corruption is positive. In determining this net effect, the "grease the wheels" effect must be weighed against the fact that the presence of corruption prevents a significant number of firms from participating in the export market itself. ${ }^{29}$

\section{References}

Ai, C., Norton, E.C., 2003. "Interaction terms in logit and probit models." Economics Letters, 80(1): 123-129. Anderson, J.E., Marcouiller, D., 2002. "Insecurity and the pattern of trade: An empirical investigation." The Review of Economics and Statistics, 84(2): 342-352.

Bhagwati, J., Hansen, B., 1973. “A Theoretical Analysis of Smuggling." Quarterly Journal of Economics, 87(2): 172187.

Blonigen, B., Wilson, W., 2008. "Port Efficiency and Trade Flows." Review of International Economics, 16(1): 2136.

Clark, X., Dollar, D., Micco, A., 2004. "Port Efficiency, Maritime Transport Costs, and Bilateral Trade." Journal of Development Economics, 75(2): 417-450.

Dal Bó, Rossi, M.A., 2007. "Corruption and Inefficiency: Theory and Evidence from Electric Utilities." Journal of Public Economics, 91(5-6): 939-962.

Djankov, S., Freund, C., and Pham, C., 2010. "Trading on Time." The Review of Economics and Statistics, 92(1): 166-173.

Dreher, A., Gassebner, M., 2013. “Greasing the Wheels? The Impact of Regulations and Corruption on Firm Entry." Public Choice, 155(3): 413-432.

Dutt, P., Traca, D., 2010. "Corruption and Bilateral Trade Flows: Extortion or Evasion." The Review of Economics and Statistics, 92(4): 843-860. 
Fisman, R., Svensson, J., 2007. "Are Corruption and Taxation Really Harmful to Growth? Firm Level Evidence." Journal of Development Economics, 83(1): 63-75.

Hummels, D., 2001. “Time as a Trade Barrier." GTAP Working Paper No. 18.

Hummels, D., Schaur, G., 2013. "Time as a Trade Barrier." American Economic Review, 103(7): 2935-2959.

Huntington, S.P., 1968. Political Order in Changing Societies. New Haven: Yale University Press.

Krueger, A.O., 1974. "The Political Economy of the Rent-Seeking Society." American Economic Review, 64(3):

291-303.

Leff, N.H., 1964. "Economic Development Through Bureaucratic Corruption." American Behavioral Scientist, 8(3): 8-14

Lui, F., 1985. "An Equilibrium Queuing Model of Bribery." Journal of Political Economy, 93(4): 760-781

Mayer, T., Ottaviano, G., 2007. "The Happy Few: New Facts on the Internationalisation of European Firms." Bruegel-CEPR EFIM2007 Report, Bruegel Blueprint Series.

Mayer, T., Zignago, S., 2011. "Notes on CEPIls Distances Measures : the GeoDist Database." CEPII Working Paper 2011-25.

Myrdal, G., 1968. Asian Drama: An Enquiry Into the Poverty of Nations (Vol. 2). New York: Twentieth Century Fund.

Nordas, H., Pinali, E., Geloso Grosso, M., 2006. “Logistics and time as a trade barrier." OECD Trade Policy Working Paper 35. Paris: OECD.

OECD, 2005. "The economic impact of trade facilitation." OECD Trade Policy Working Paper 21. Paris: OECD.

Olken, B.A., Pande, R., 2012. "Corruption in Developing Countries." Annual Review of Economics, 4: 479-509.

Olney, W., 2015. "Impact of Corruption on Firm-Level Export Decisions." Economic Inquiry, 54(2): 1105-1127.

This article is protected by copyright. All rights reserved. 
Rauch, J., 1999. "Networds versus Markets in International Trade." Journal of International Economics, 48(1): 735.

Rose-Ackerman, S., 1999. Corruption and Government: Causes, Consequences, and Strategies for Reform. Cambridge: Cambridge University Press.

Sequeira, S., Djankov, S., 2014. "Corruption and Firm Behavior: Evidence from African Ports." Journal of International Economics, 94(2): 277-329.

Shleifer, A., Vishny, R., 1993. "Corruption." Quarterly Journal of Economics, 108(3): 599-617.

Smith, R., Blundell, R., 1986. “An Exogoneity Test for a Simultaneous Equation Tobit Model with an Application to Labor Supply." Econometrica, 54(3): 679-685.

Volpe Martincus, C., Carballo, J., Graziano, A., 2015. “Customs." Journal of International Economics, 96(1): 119137.

Wei, SJ, 1997. "Why is Corruption so Much More Taxing Than Tax? Arbitrariness Kills." National Bureau of Economic Research Working Paper No. 6255.

Wilson, J.S., Mann, C.L., Otsuki, T., 2004. “Assessing the potential benefit of trade facilitation: A global

perspective." World Bank Working Paper Series 3224. Washington DC: World Bank.

Wooldridge, J.M., 2010. Econometric Analysis of Cross Section and Panel Data. Cambridge, MA: MIT Press.

World Bank, 2005. Doing Business in 2006: Creating Jobs. Washington, D.C.

World Bank, 2007. Connecting to Compete: Trade Logistics in the Global Economy. Washington, D.C.

Figure 1: Variation in Bribes Paid by Exporters Across Countries

Figure 2: Trends in Customs-Related Red Tape by Country

Figure 3: Marginal Effect and 95\% Confidence Interval of Documents Needed to Export at Various Deciles of

This article is protected by copyright. All rights reserved. 


\section{Corruption Prevalence}

Table 1: Countries in the Sample by Region

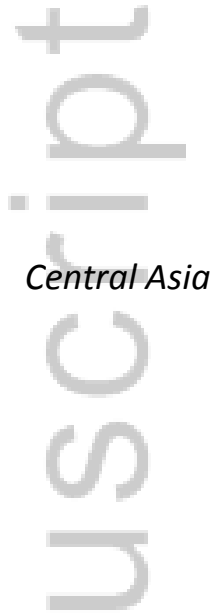

Armenia, Georgia, Kazakhstan,

Kyrgyz Republic, Tajikistan,

Uzbekistan

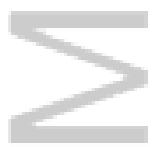

\section{European Union}

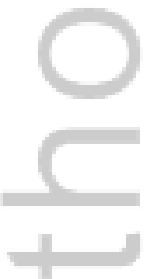

Bulgaria, Croatia, Czech Republic,

Estonia, Hungary, Latvia,

Lithuania, Poland, Romania,

Slovakia, Slovenia

This article is protected by copyright. All rights reserved. 

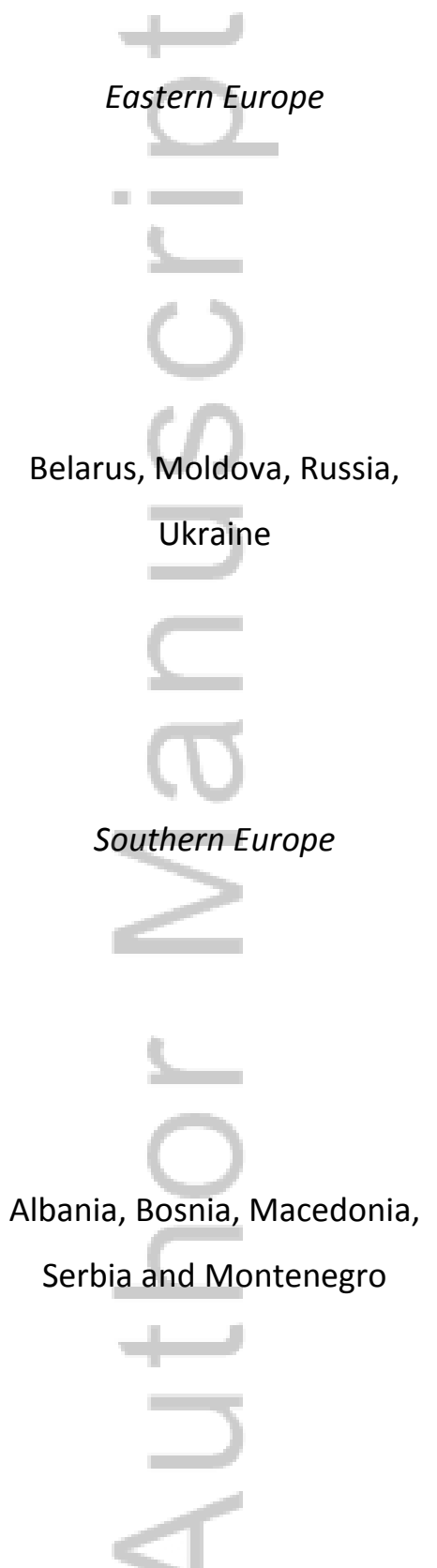

Notes: The original sample includes 27 countries. I omit Azerbaijan as there are no firms from this country in the sample in 2005. In addition, I merge Serbia and Montenegro as they first appear in the data as separate countries in 2008.

This article is protected by copyright. All rights reserved. 
Table 2: Corruption and Customs as Barriers to Firms

2005

2008

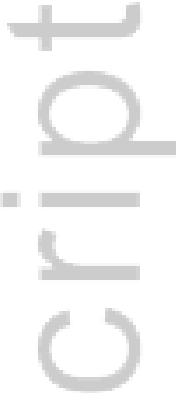

Fraction of firms

that
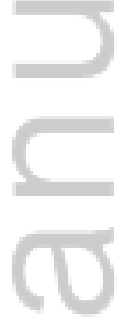

Pay bribes to

0.36

0.29

customs officials

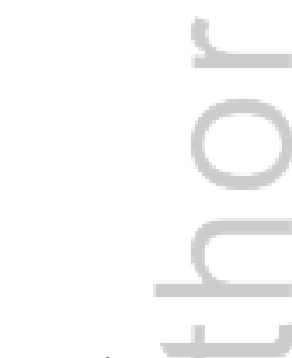

Consider customs

and trade

regulations to be

an obstacle 


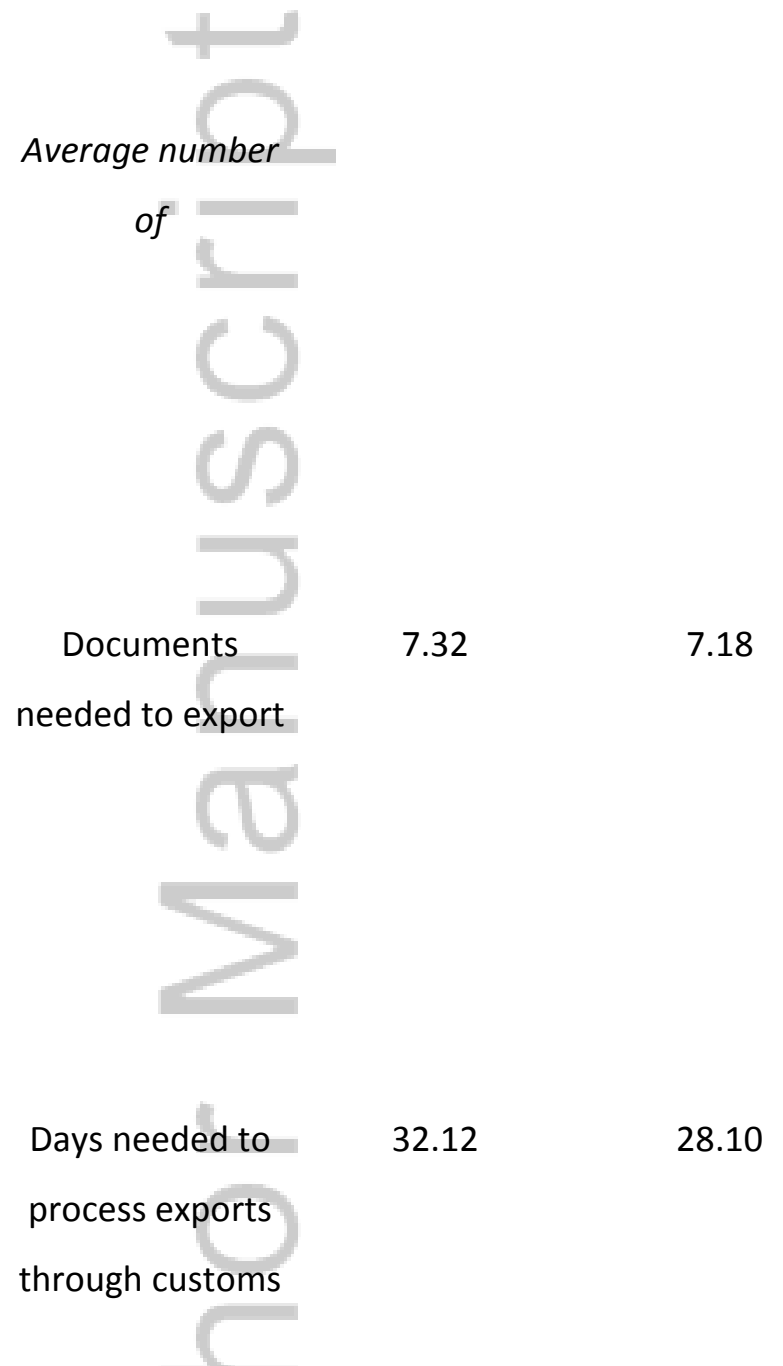

Notes: The numbers in the first two rows are calculated using firm-level data from the Business Environment and Enterprise Performance Surveys while the numbers in the last two rows are calculated using country-level data from the Doing Business reports.

Table 3: Summary Statistics

Non-

This article is protected by copyright. All rights reserved. 


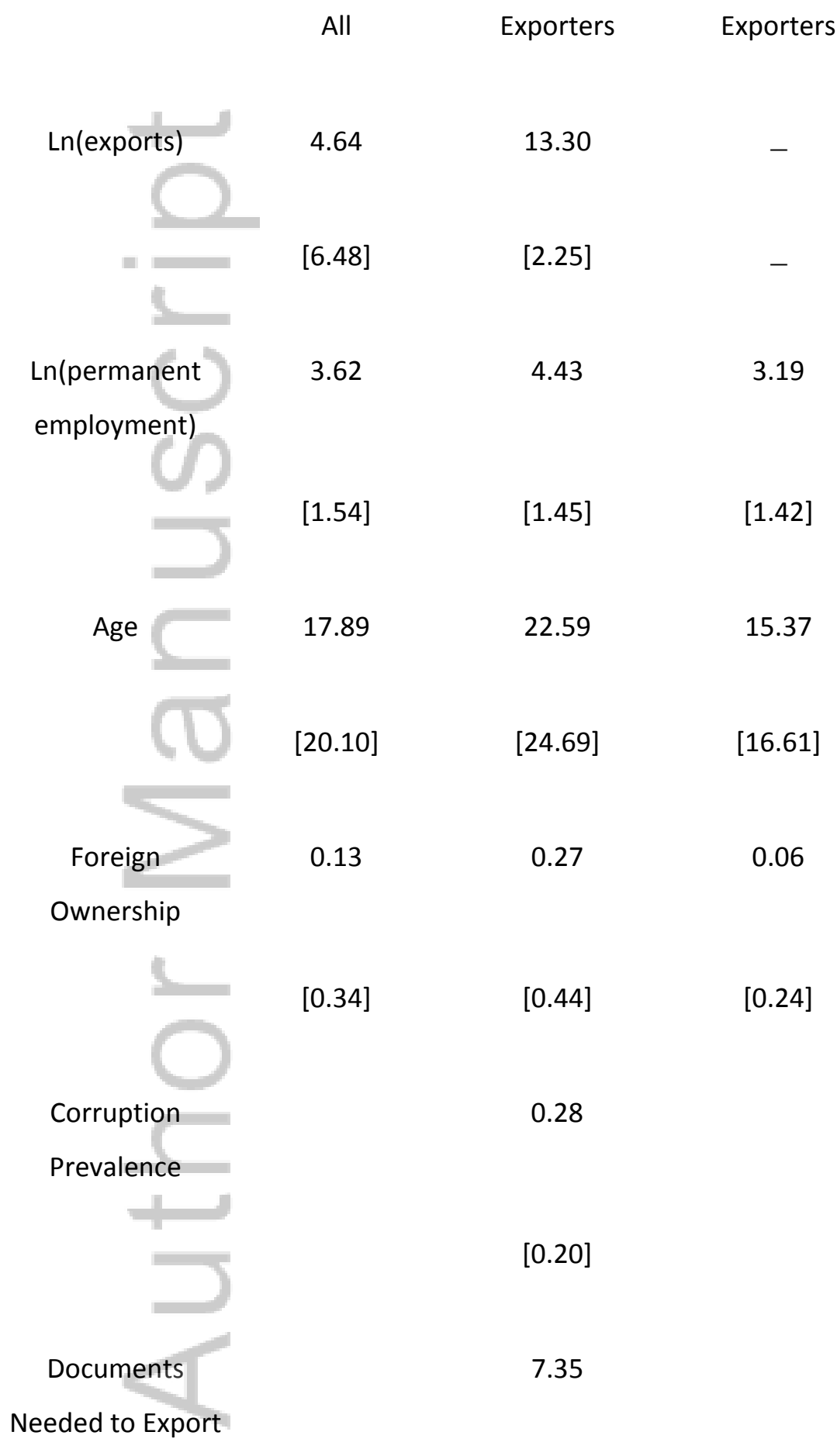

This article is protected by copyright. All rights reserved. 
Days Needed to

\section{Process Exports}

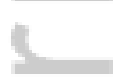

Observations
31.50

[23.08]

1,892
3,530

\section{(4)}

5,422

1,892

\section{3,530}

Notes: For each variable above, I report the mean and standard deviation (in brackets). Corruption prevalence is defined as the fraction of firms in an industry and country that pay bribes to customs officials. All monetary values are in constant 2005 U.S. dollars.

Table 4: Baseline Results

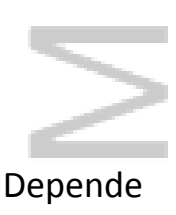

nt Variable

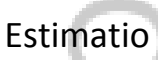

n Method

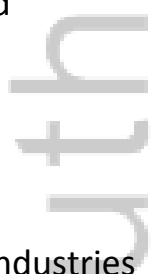

(1)

Ln(exports)
(2)

OLS

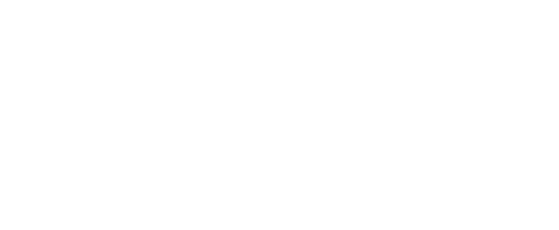

All
(3)

(4)

(5)

Tobit
Time-

Sensitive
(6)

All

All
Included 


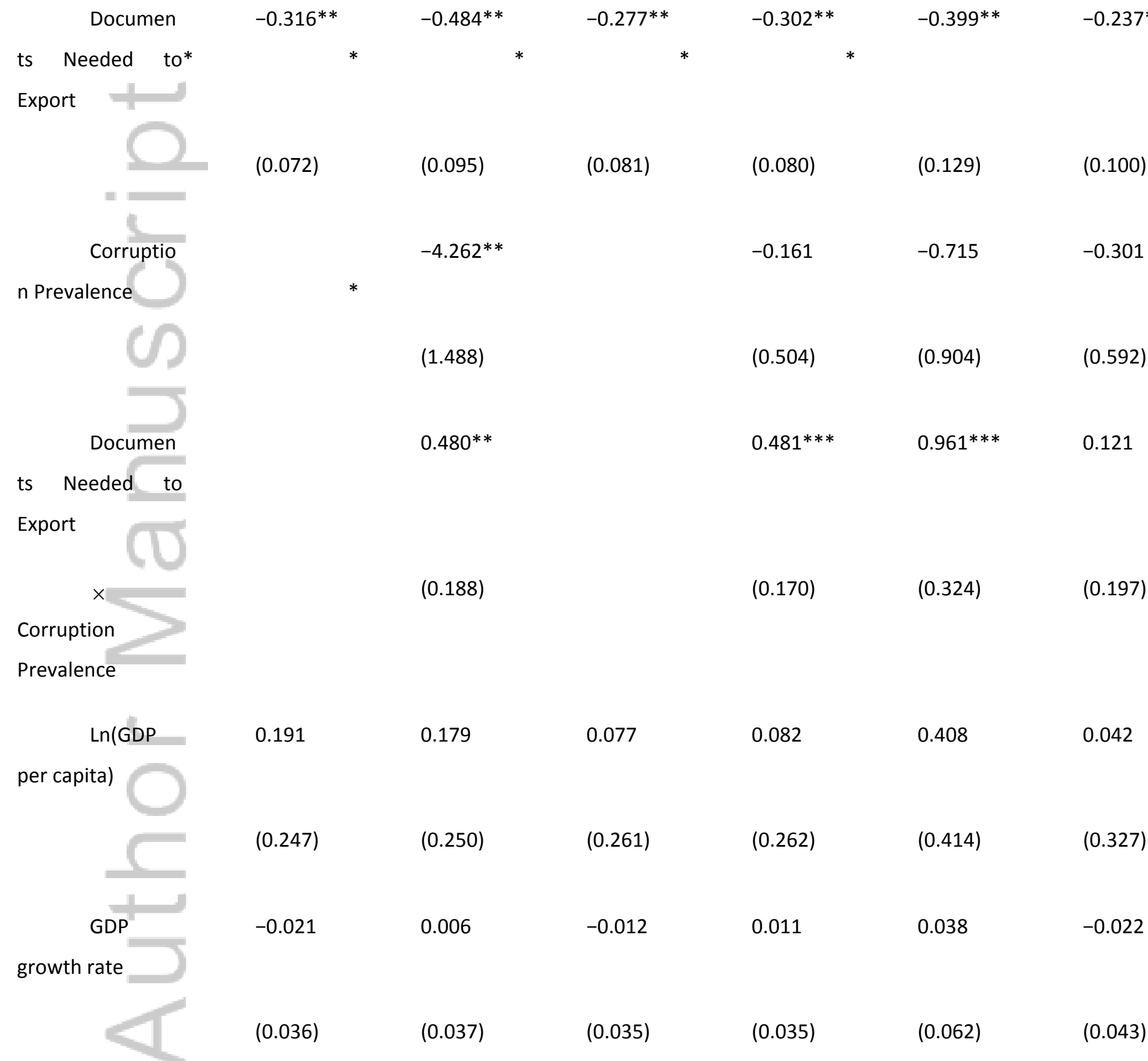

This article is protected by copyright. All rights reserved. 

Observati
5,422
5,422
5,422
5,422
2,076
2,536

ons

R-

0.358

0.360

$-8916.05$

$-8909.98$

$-3864.60$

$-3860$.

squared/Log

likelihood

Notes: The numbers reported in columns (1) and (2) are coefficient estimates and their standard errors in parenthesis. The numbers reported in columns (3) to (6) are marginal effects and its standard errors in parenthesis. The marginal effects are the effect of each variable on $\mathrm{E}[\ln (X)]$ where $X$ represents exports. In column (5) the sample is restricted to time-sensitive industries while in column (6) the sample is restricted to time-insensitive industries. See section 5.1 for details on how industries are placed in these two categories. All regressions include the natural logarithm of total permanent employees, firm age, age squared, an indicator for whether a firm has foreign ownership, and a constant that is not reported. All regressions also include region fixed effects as well as industry and year interaction fixed effects. The standard errors in parenthesis in columns (1) and (2) are robust and clustered at the industry-country level. The standard errors in parenthesis in columns (3) to (6) are calculated using the delta method. ${ }^{* *} \mathrm{p}<0.01,{ }^{* *} \mathrm{p}<0.05, * \mathrm{p}<0.1$

center

Table 5: Additional Industry Characteristics - Tobit Marginal Effects

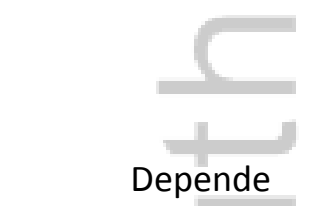

nt Variable

\section{Additiona}

I Industry
$\operatorname{Ln}($ exports)
(2)

(3)

(4)

(5)

Skill

Labor

Fraction

Fraction

Air-

This article is protected by copyright. All rights reserved. 


$\begin{array}{llll}\text { Character Sales } \quad \text { Intensity } & \text { Productivi } & \text { Shipped }\end{array}$

istic Included

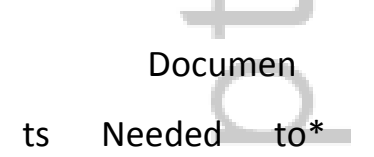

Export

$=$

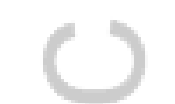

Corruptio

(0.078)

$-0.171$

(0.505)

$0.441^{* * *}$

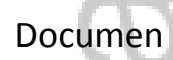

ts Needed to

Export

$$
\times
$$

Corruption

Prevalence

Observati

ons

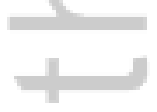

$$
\text { Log }
$$

likelihood
$0.496 * *$

(0.516)

(0.496)

(0.498)

(0.535)

ty

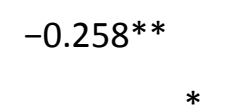

(0.080)

$-0.143$

$-0.249$

$-0.200$

(0.077)

(0.082)

$-0.079$

$0.419 * *$

$0.467^{* *}$

$0.504^{* *}$
(0.163)

(0.239)

(0.200)

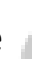
d
5,422

5,397

5,422

5,422

5,310

$-8888.44$

$-8902.76$

Notes: The marginal effects reported in all columns are the effect of each variable on $\mathrm{E}[\ln (X)]$ where $X$ represents exports. Columns (1) to (3) each include an additional industry characteristic along with its interaction with the number of documents needed to export. In column (4) I include the interaction between the number of 
documents needed to export and the fraction of an industry's exports to the U.S. that are shipped by air. As my measure of air shipment is time invariant, it's level effect is absorbed by the industry and year interaction fixed effects. In column (5) I include the interaction between the number of documents needed to export and the fraction of an industry's products that are differentiated according to the Rauch (1999) classification. All regressions include the natural logarithm of total permanent employees, firm age, age squared, an indicator for whether a firm has foreign ownership, the natural logarithm of GDP per capita, the growth rate of GDP, and a constant that is not reported. All regressions also include region fixed effects as well as industry and year interaction fixed effects. The standard errors in parenthesis are calculated using the delta method. ${ }^{* * *} p<0.01$, $* * p<0.05, * p<0.1$

center

Table 6: Endogeneity of Corruption Prevalence

(1)

(3)

Depende Ln(exports)

nt Variable

Estimatio

IV-2SLS

n Method

Documen

ts Needed to*

Export

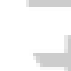

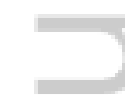

Corruptio

n Prevalence

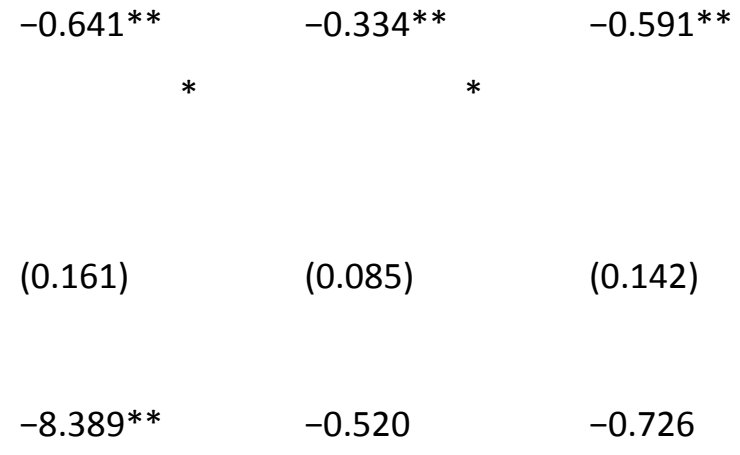

$\begin{array}{lll}-8.389 * * & -0.520 & -0.726\end{array}$ 
Documen

0.919**

$1.036^{* * *}$

$2.340 * * *$

ts Needed to

Export

Corruption

Prevalence

P-value

$-$

[0.023]

[0.006]

$\left[H_{0}: \hat{v}_{1}=0\right.$ ]

P-value

$\left[H_{0}: \hat{v}_{2}=0\right.$ ]

Landlocke

No

No

Yes

d Countries

[0.016]

Excluded

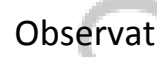

5,422

5,422

3,554

ons

$\log$

$-$

$-8905.78$

$-6044.98$

likelihood

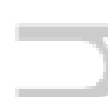

Notes: The marginal effects reported in columns (2) and (3) are the effect of each variable on $\mathrm{E}[\ln (X)]$ where $X$ represents exports. $\hat{v}_{1}$ and $\hat{v}_{2}$ are the estimated residuals from the first-stage regressions. These are explained in detail in section 5.2. All regressions include the natural logarithm of total permanent employees, firm age, age squared, an indicator for whether a firm has foreign ownership, the natural logarithm of GDP per capita,

This article is protected by copyright. All rights reserved. 
the growth rate of GDP, and a constant that is not reported. All regressions also include region fixed effects as well as industry and year interaction fixed effects. The standard errors in column (1) are robust and clustered at the industry-country level. The standard errors in parenthesis in columns (2) and (3) are calculated using the delta method. $* * * p<0.01, * * p<0.05, * p<0.1$

$$
\text { center }
$$

Table 7: Other Country Characteristics - Tobit Marginal Effects

$(1)$

$\operatorname{Ln}($ exports) nt Variable

Depende
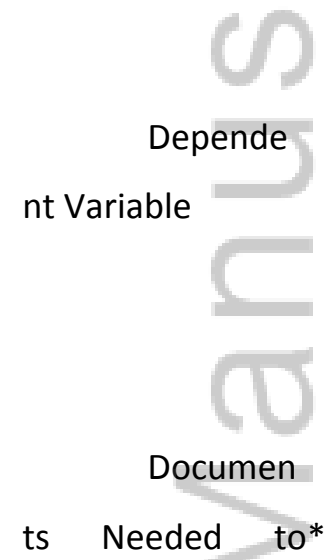

Documen

ts Needed to*

Export
(2)

(3)

(4)

(5)

$\begin{array}{llllll} & (0.080) & (0.080) & (0.081) & (0.080) & (0.081) \\ \text { Corruptio } & 0.016 & -0.148 & -0.160 & -0.122 & 0.005 \\ \text { n Prevalence } & & & & (0.499) \\ \text { ts Needed to } & (0.511) & (0.507) & (0.495) & 0.471^{* * *} & 0.356^{* *} \\ \text { Export } & & & & \end{array}$

This article is protected by copyright. All rights reserved. 
$\times$

(0.161)

(0.169)

(0.168)

(0.170)

(0.159)

Corruption

Prevalence

Exports /

$0.024 * *$

$0.023 * *$

GDP

$=1$
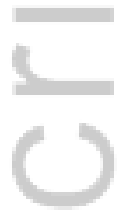

(0.011)

(0.011)

Landlocke

0.181

d

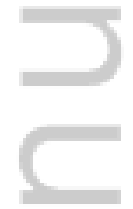

(0.384)

Regulator

y Quality

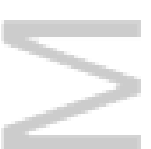

$0.981^{*}$

0.890*

$(0.548)$

(0.527)

Procedur

0.133

es to Start a

Business

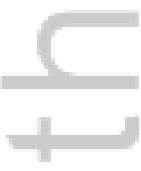

Observati

5,422

5,422

5,422

5,422

5,422

ons

$\log$

$-8901.23$

$-8909.58$

$-8903.64$

$-8908.04$

$-8896.02$

likelihood

This article is protected by copyright. All rights reserved. 
Notes: The marginal effects reported in all columns are the effect of each variable on $\mathrm{E}[\ln (X)]$ where $X$ represents exports. All regressions include the natural logarithm of total permanent employees, firm age, age squared, an indicator for whether a firm has foreign ownership, the natural logarithm of GDP per capita, the growth rate of GDP, and a constant that is not reported. All regressions also include region fixed effects as well as industry and year interaction fixed effects. The standard errors in parenthesis are calculated using the delta method. *** $p<0.01, * * p<0.05, * p<0.1$

$$
\text { center }
$$

Table 8: Robustness Checks - Tobit Marginal Effects

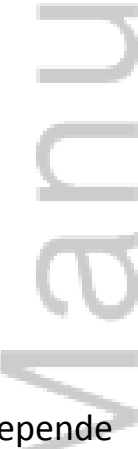

$$
\text { Depende }
$$

nt Variable

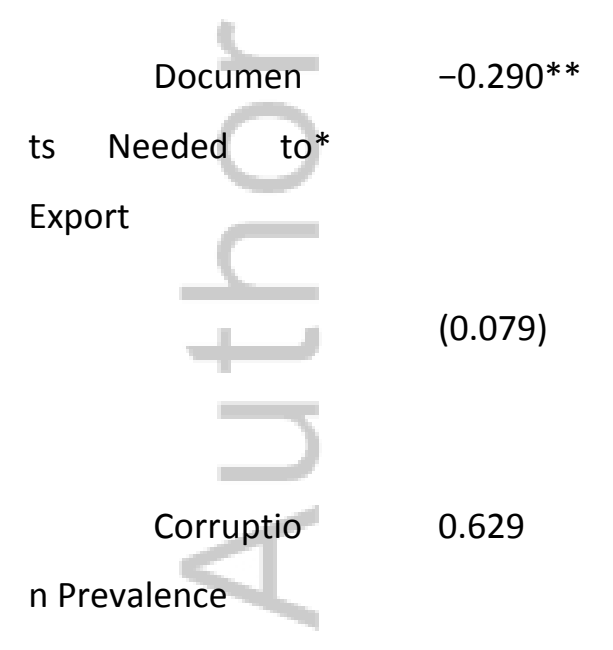

(2)

(4)

(5)

$$
\text { Export / Ln(all }
$$

Sales

exports)
Sales

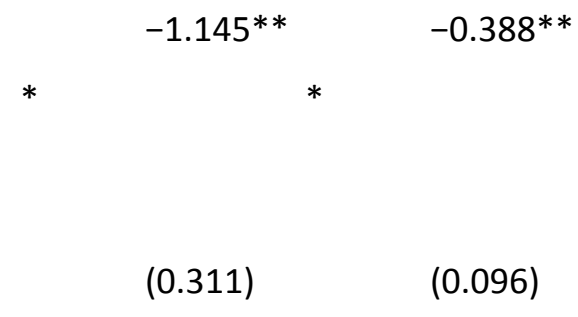

This article is protected by copyright. All rights reserved. 
(Time

Invariant)

Documen

Export

$\times$

Corruption

Prevalence

(Time

Invariant)

$$
\text { Corruptio }
$$

n Prevalence

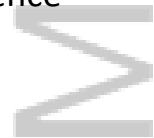

ts Needed to

Export

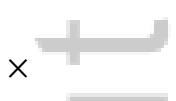

Corruption

Prevalence

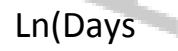

Needed

to

Process Exports)
(0.495)

$0.465^{* * *}$

(0.155)
(0.560)

(0.684)

(0.188) 
(0.375)

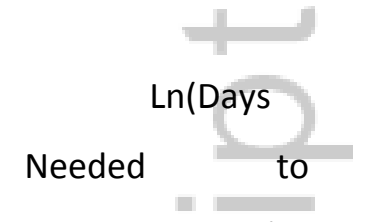

$1.843^{* *}$

Process Exports)

$\times$

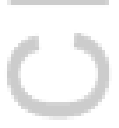

(0.760)

Corruption

Prevalence

LPI Index -

$-2.526^{* *}$

Customs
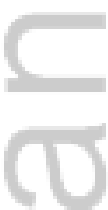

(0.620)

LPI Index -

$3.364 * *$

Customs $x$

Corruptio

n Prevalence

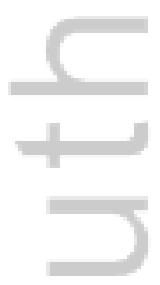

Observati

5,422

5,422

5,313

5,422

5,422

ons

This article is protected by copyright. All rights reserved. 
Notes: The dependent variable in columns (1) to (4) includes only direct exports. In contrast, the dependent variable in column (5) includes both direct exports as well as indirect exports. The marginal effects reported in all

columns are the effect of each variable on $\mathrm{E}[\ln (X)]$ where $X$ represents exports. The corruption prevalence variable in column (1) is time invariant. In the remaining columns, the corruption prevalence variable is the default one. LPI Index - Customs is the customs-specific logistics performance index score for each country. A higher value of this score represents less efficient customs. All regressions include the natural logarithm of total permanent employees, firm age, age squared, an indicator for whether a firm has foreign ownership, the natural logarithm of GDP per capita, the growth rate of GDP, and a constant that is not reported. All regressions also include region fixed effects as well as industry and year interaction fixed effects. The standard errors in parenthesis are calculated using the delta method. ${ }^{* * *} p<0.01,{ }^{* *} p<0.05,{ }^{*} p<0.1$

center

Table 9: Extensive Margin Effects by Firm and Industry Characteristics - Probit Marginal Effects

(1)

$(2)$

Export Indicator
Depende

nt Variable

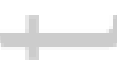

Firms/Ind

ustries Included
Time-

Time-

All

Sensitive
(4)

(5)
Large

e
Insensitiv 


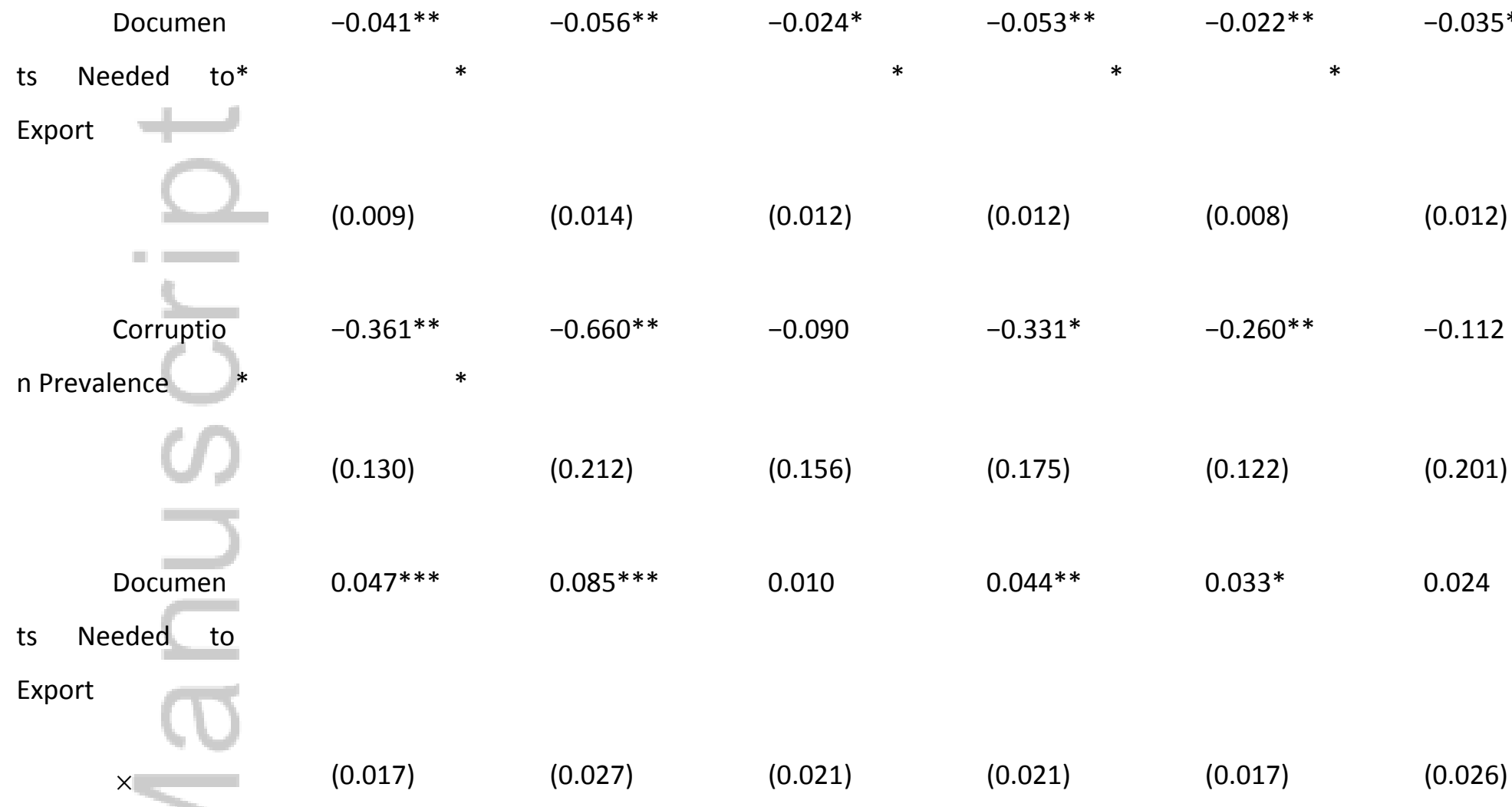

Corruption

Prevalence

$$
5,422
$$

2,076

2,536

2,719

2,703

2,885

ons

Log

$-2636.20$
$-1077.36$

$-1203.76$
$-1513.59$
$-1508$.

likelihood

Notes: The dependent variable in all columns is an indicator that is one if a firm is an exporter and zero otherwise. The marginal effects reported in all columns represent the effect of each variable on $\operatorname{Pr}[X>0]$ where $X$ represents exports. In column (2) the sample is restricted to time-sensitive industries while in column (3) the 
sample is restricted to time-insensitive industries. See section 5.1 for details on how industries are placed in these two categories. In columns (4) and (5) the sample is restricted to large and small firms respectively. Large firms are defined as firms with permanent employment greater than or equal to the sample median. All other firms are classified as small. Finally, in columns (6) and (7) the sample is restricted to old and young firms respectively. Old firms are defined as those that have an age that is greater than or equal to the sample median. All other firms are classified as new. All regressions include the natural logarithm of total permanent employees, firm age, age squared, an indicator for whether a firm has foreign ownership, the natural logarithm of GDP per capita, the growth rate of GDP, and a constant that is not reported. All regressions also include region fixed effects as well as industry and year interaction fixed effects. The standard errors in parenthesis are calculated using the delta method. ${ }^{* * *} p<0.01, * * p<0.05, * p<0.1$
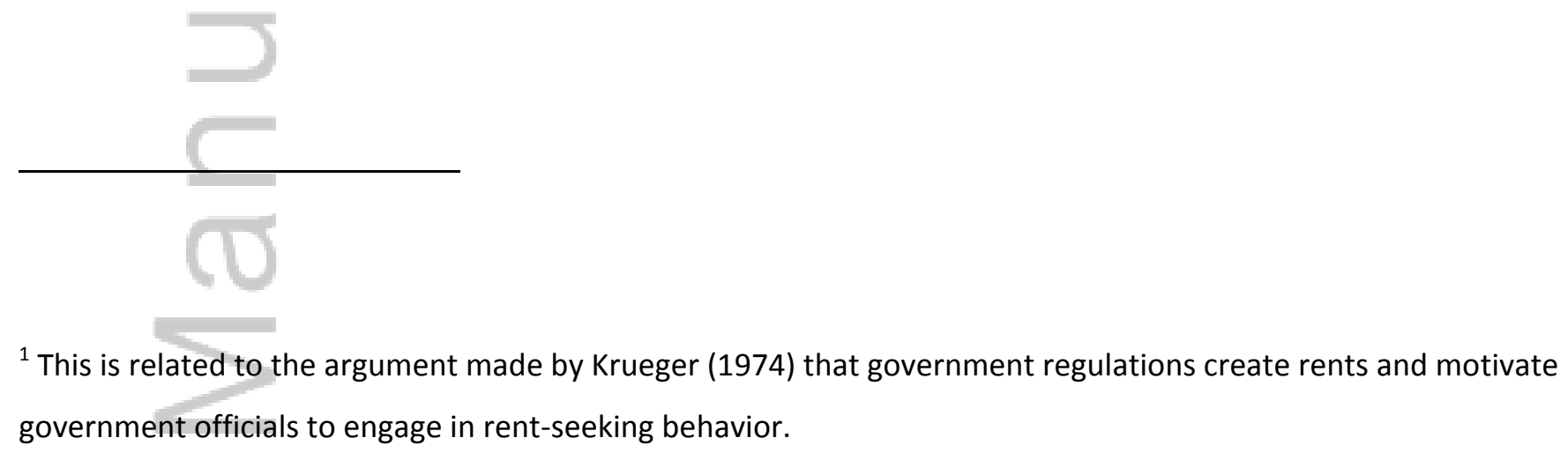
government officials to engage in rent-seeking behavior.

${ }^{2}$ In fact, corruption may have other adverse effects that have not been empirically explored in this paper. For instance, we know that corruption can create uncertainty (Wei, 1997), it can lead to firms making costly production choices to lower their exposure to corruption (Sequeira and Djankov, 2014), and by being able to use bribes to avoid detection and punishment, corruption may encourage firms to engage in illegal activities (Olken and Pande, 2012). To the extent that these adverse effects dominate the "grease the wheels" effect, the net effect of corruption will be negative.

${ }^{3}$ Dutt and Traca's result is related on an earlier theoretical literature that examines the possible trade-increasing effects of using smuggling to evade tariffs (Bhagwati and Hansen, 1973).

\footnotetext{
${ }^{4}$ The online appendix can be downloaded from the following url: https://sites.google.com/site/reshadahsan.
} 
${ }^{5}$ To get a better sense of what $\theta$ represents, suppose that the firm has a manager that is endowed with a finite amount of time, which I also normalize to one. The manager spends a fraction $\theta$ of her time waiting at customs for her customs-related documents to be processed. The manager spends the remaining $(1-\theta)$ of her time supervising production. This means that greater customs-related delays cause a reduction in a firm's exports by diverting its manager's time away from supervising production and towards dealing with red tape. Dal Bó and Rossi (2007) use a similar approach to model a manager's decision to allocate her effort between supervising production and negotiating a better price for her firm's product.

${ }^{6}$ Corruption can have an additional adverse effect on exports by allowing customs officials to cause further delays to extract a higher bribe (Myrdal, 1968). In particular, suppose that the upper bound on the delay faced by a firm is $\bar{\theta}>\theta_{H}$. That is, due to imperfect monitoring, the customs official now has the ability to impose a delay that is greater than that mandated by the government. It could now be the case that the result of the bribe is to lower the delay the firm faces to some level $\theta^{\prime} \geq \theta_{H}$. In other words, the result of corruption is to lower the delay to a level that is not better than what it would have been if the customs officials did not have the ability to extract bribes from exporters.

${ }^{7}$ In addition, the presence of corruption at customs can create three additional costs. First, such corruption can induce uncertainty regarding the actual delay faced by exporters. This uncertainty can have a negative effect on firms (Wei, 1997). Second, the presence of corruption may encourage exporters to engage in costly production choices to circumvent their exposure to corruption (Sequeira and Djankov, 2014). Lastly, to the extent that red tape is socially valuable, for example if it was designed to prevent illegal behavior, then a bribe that lowers red tape will impose additional social costs (Olken and Pande, 2012). To the extent that these additional adverse effects are important, it is more likely that the overall effect of corruption is negative even if it does allow exporters to attenuate the adverse effects of red tape.

This article is protected by copyright. All rights reserved. 
${ }^{8}$ The data are publicly available at www.enterprisesurveys.org. These data were also collected in 2002 for the countries in my sample. However, the 2002 data did not include the industry to which each firm belonged. Further, the data on export red tape that I use in the paper are also not available for this year. For these reasons, I restrict the sample to 2005 and 2008.

${ }^{9}$ Surveys that try to elicit such sensitive information must deal with some firms' unwillingness to participate. Several key steps were taken to address this concern. First, in order to ensure maximum participation the surveys were conducted by local consultants (usually in cooperation with local business organizations) hired by the World Bank. This was done to allay fears that the information collected in the survey would be used in future to target particular establishments. In addition, questions regarding bribery were asked in an indirect manner in order to extract as honest an answer as possible.

${ }^{10}$ In addition to the classification issue discussed above, the raw bribery response variable has the disadvantage of providing an ordinal ranking of corruption faced by firms. This makes it relatively more cumbersome to interpret its regression coefficient. The binary corruption variable that I have constructed does not have this drawback.

${ }^{11}$ For the three countries in their sample for which they have representative data, the share of exporters ranges from 28 percent in the U.K. to 40 percent in Norway and 48 percent in Hungary. The data for the remaining three countries (France, Germany, and Italy) are skewed towards larger firms. As a result, the share of exporters in these countries are considerably higher.

${ }^{12}$ I estimate equation (2) using a sample that consists of both exporters and non-exporters. This approach is superior to estimating (2) using a sample of only those firms that export since this latter approach involves throwing away information on firms that optimally choose not to export. Further, by restricting the sample to exporters only, I cannot rule out the fact that my key results are being driven by non-random compositional changes in the sample. To account for the non-exporters, I add USD 1 to each firm's exports before taking the natural logarithm of the dependent variable in (2).

This article is protected by copyright. All rights reserved. 
${ }^{13}$ I construct these fixed effects by dividing the sample of countries into four regions: (a) European Union (EU), (b) Central Asia and Caucasus (c) Southern Europe and (d) Eastern Europe (non EU). I then include the fixed effects for the EU, Central Asia, and Southern Europe in equation (2). The list of countries in each region is listed in Table 1.

${ }^{14}$ As Figure 2 demonstrates, there is very little time variation in the number of documents needed to export. As a result, including country fixed effects in equation (2) will absorb most of the variation in $D_{c t}$. Instead, I include country-level controls and region fixed effects to capture country characteristics that are correlated with $D_{c t}$.

${ }^{15}$ Fisman and Svensson (2007) face a similar problem when they estimate the effect of firm-level bribes on firm growth. They instrument firm-level bribes using the average bribes paid in an industry-location pair. Their identification assumption is identical to mine, i.e. that the average bribes paid in an industry-location is uncorrelated with the error term in the firm-level regression. Thus, from this perspective, there is no advantage to using this IV approach. In contrast, this IV approach has a clear drawback, which is that it will lead to the omission of firms that do not report bribes. For instance, 9.3 percent of firms in my working sample do not provide an answer to the question on bribes paid to customs officials. If I were to use the Fisman and Svensson (2007) IV approach, these firms would be omitted. In contrast, by using the industry average in place of firm-level bribes, I am able to retain these firms in my analysis.

${ }^{16}$ My choice of calculating $\vec{B}_{j c^{\prime} t}$ using a set of contiguous countries better ensures that the patterns of comparative advantage are common across country pairs $c$ and $c^{\prime}$. This will maximize the correlation between $B_{j c t}$ and $B_{j c^{\prime} t}$.

${ }^{17}$ An alternate approach is to restrict the sample to firms with positive exports and then use a Heckman-style selection correction. Unfortunately, the lack of an appropriate exclusion restriction makes this option less attractive. 
${ }^{18}$ Note that the coefficient of both country-level control variables, the natural logarithm of GDP per capita and the GDP growth rate, are statistically insignificant in columns (1) and (2). In fact, this is the case in all columns of Table

4.

${ }^{19}$ If I were to estimate equation (2) using OLS, then $\beta_{1}$ would be the "level" effect of $D_{c t}$ and $\beta_{1}+\beta_{3} \bar{B}_{j t}$ would the total effect of $D_{c t}$. However, when equation (2) is estimated using Tobit, the total effect of $D_{c t}$ is given by equation (4).

${ }^{20}$ The estimates suggest that in industries in the highest corruption prevalence decile, adding one more document needed to export raises firm exports. However, this estimate is statistically insignificant with a p-value of 0.80 .

${ }^{21}$ This method relies on the regression results of Hummels (2001), who examines how air shipment costs and ocean shipment times affect the probability of choosing air transport. In particular, he regresses an indicator for whether or not a shipment arrived in to the U.S. by air on the ratio of ocean shipment days and air freight charges (days/rate ratio). He ran these regressions for each two-digit SITC industry in his sample. Following Volpe Martincus et al. (2015), I categorized a two-digit SITC industry as having time-sensitive products if the days/rate ratio coefficient for that industry is positive and statistically significant. All other industries are classified as having time-insensitive products. I then created a cross-walk between the SITC categorization in Hummels (2001) and the ISIC two-digit industries in my sample. Table C.2 in the online appendix lists the industries in my sample that I was able to categorize in this manner. Two industries, "printing of recorded media" and "repair of machinery", could not be classified. These two industries did not have equivalent industries in Hummels' analysis. Djankov et al. (2010) also use a similar method to categorize their industries as having either time-sensitive or time-insensitive products.

${ }^{22}$ It could also be the case that corruption mainly affects a firm's exports indirectly by distorting its access to imported inputs. To examine whether this is the case, I compare the effects of corruption on firm exports for firms 
that are imported-input intensive versus those that are not. I classify a firm as imported-input intensive if its ratio of imported to all materials is greater than or equal to the sample median. After comparing the results, I find that the overall effect of corruption in both sub-samples is statistically insignificant. Further, I find that the magnitude of the interaction effect is similar in both sub-samples, although it is only precisely estimated for the domesticinput intensive sub-sample. These results suggest that the indirect imported-input channel is not a key determinant of the baseline results of this paper.

${ }^{23}$ Because the fraction of air shipment variable that I calculate is time-invariant, its level effect is captured by the industry and year interaction fixed effects.

${ }^{24}$ Once again, this fraction of differentiated products is time-invariant and its level effect is captured by the industry and year interaction fixed effects.

${ }^{25}$ To calculate the marginal effects in this case I first use the adjustment factor suggested by Wooldridge (2010, pp. 681-685) and then use the derivations listed in (4) to (6).

${ }^{26}$ The coefficients of $\hat{v}_{1, i j c t}$ and $\hat{v}_{2, i j c t}$ suggest that we can reject the null that $B_{j c t}$ and $B_{j c t} \times D_{c t}$ are exogenous. Despite this, I chose to feature the baseline results rather than the instrumental variable ones in this paper because the former provide more conservative estimates.

${ }^{27}$ A regression of the number of documents needed to export on country fixed effects alone yields an $R^{2}$ of 0.98 .

${ }^{28}$ The index is provided as an overall score for each country as well as for specific logistical aspects. I use the index score that is specific to customs. On average, having a LPI higher by one point means that an exporter has to wait three additional days to export (World Bank, 2007).

${ }^{29}$ Further, corruption may have other adverse effects that have not been empirically explored in this paper. For instance, corruption can create uncertainty (Wei, 1997), it can lead to firms making costly production choices to 
lower their exposure to corruption (Sequeira and Djankov, 2014), and by being able to use bribes to avoid detection and punishment, corruption may encourage firms to engage in illegal activities (Olken and Pande, 2012). To the extent that these adverse effects dominate the "grease the wheels" effect, the net effect of corruption will be negative.
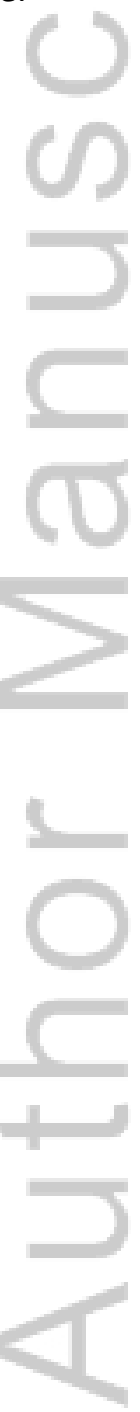

This article is protected by copyright. All rights reserved. 


\section{University Library}

\section{- M M I E E R VA A gateway to Melbourne's research publications}

Minerva Access is the Institutional Repository of The University of Melbourne

Author/s:

Ahsan, RN

Title:

DOES CORRUPTION ATTENUATE THE EFFECT OF RED TAPE ON EXPORTS?

Date:

2017-07-01

Citation:

Ahsan, R. N. (2017). DOES CORRUPTION ATTENUATE THE EFFECT OF RED TAPE ON EXPORTS?. ECONOMIC INQUIRY, 55 (3), pp.1192-1212. https://doi.org/10.1111/ ecin.12445.

Persistent Link:

http://hdl.handle.net/11343/292585 